EDUCATIONAL EXPERIENCES OF STUDENTS LEARNING ENGLISH:

DECONSTRUCTING BARRIERS

A dissertation submitted to the faculty of

San Francisco State University

In partial fulfillment of

the Requirements for

the Degree

Doctor of Education

In

Educational Leadership

by

Ashley Elizabeth Waggle

San Francisco, California

May 2020 
Copyright by

Ashley Elizabeth Waggle

2020 


\section{CERTIFICATION OF APPROVAL}

I certify that I have read Educational Experiences of Students Learning English:

Deconstructing Barriers by Ashley Elizabeth Waggle, and that in my opinion this work meets the criteria for approving a dissertation submitted in partial fulfillment of the requirements for the degree: Doctor of Education in Educational Leadership at San Francisco State University.

Maria del Rosario Zavala, Ph.D.

Assistant Professor

Department of Elementary Education

Heather Clary-Wheeler, Ed.D.

Principal, Foothill Elementary

Sierra Unified School District

Jean Gottlob, Ed.D.

Principal, Ohlone Elementary

Pajaro Valley Unified School District 


\title{
EDUCATIONAL EXPERIENCES OF STUDENTS LEARNING ENGLISH: DECONSTRUCTING BARRIERS
}

\author{
Ashley Elizabeth Waggle \\ San Francisco State University \\ 2020
}

Institutional practices that perpetuate tensions between a professional imperative to improve student outcomes with the chronic practices that maintain institutional barriers have conditioned language learners to feel responsible for their own academic achievement, but have not conditioned educators to feel proportionally responsible for effective instructional practices or improved student outcomes in the same way. These tensions are especially deep-rooted in high-poverty schools where majority-minoritized student populations are inducted into their educational experiences primarily by a majority white teaching staff. Emphasis on aesthetic care instead of academic achievement can maintain unacknowledged structural biases that promote the idea of white benevolence while masking a lack of challenging academic standards and white supremacist underpinnings.

I certify that the Abstract is a correct representation of the content of this dissertation. 


\section{ACKNOWLEDGEMENTS}

My deepest appreciation to every one of the social justice scholars and practitioners who make up this inspiring, inclusive cohort family. We've been told from the very beginning that there was a bumper crop of qualified applicants the year we started this journey together and having struggled and celebrated with you all over the past three years, I can't imagine this experience without the support and solidarity of this community of \#expensive friends.

This dissertation would not have been possible without the willing participation of the participants in sharing and trusting me with their stories. And the listening and retelling of your stories forever changed my perceptions... as a researcher, as an educator, and as a person.

To my dissertation chair, Maria del Rosario Zavala, your supportive feedback and consistent encouragement in the final phases of this project really helped me start to see myself as a worthy voice and scholar in the field of equity education. To my committee members, Heather Clary-Wheeler and Jean Gottlob, your critical insights helped me to articulate the findings of this study in a way that reminded me to be brave enough to name unacknowledged institutional barriers while remaining compassionate in humanizing the people maneuvering them.

And to my parents, Marlys Ash Waggle and Allyn Waggle, thank you for your continued example of persistence, perseverance, and resilience. 


\section{TABLE OF CONTENTS}

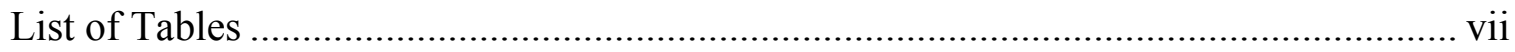

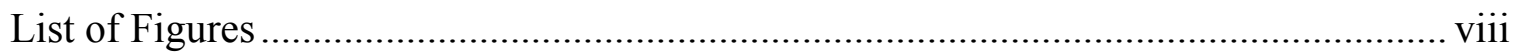

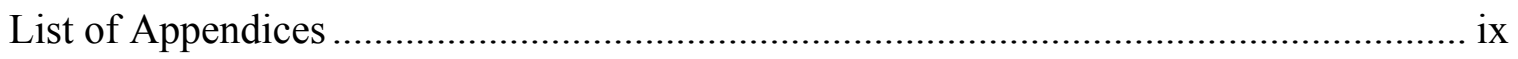

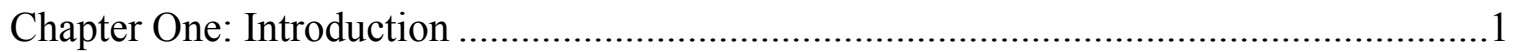

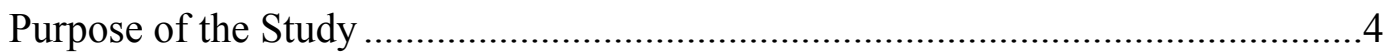

Research Questions and Design ....................................................................

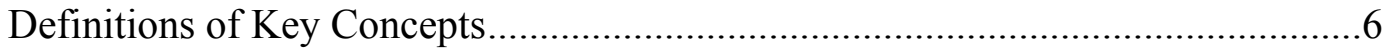

Statement of Delimitations and Scope of Study ……........................................

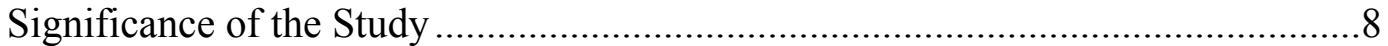

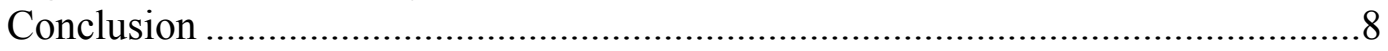

Chapter Two: Literature Review …………………...............................................10

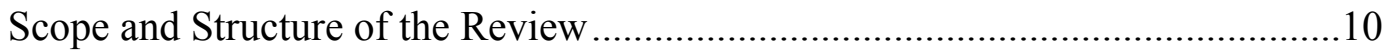

Troubling Best Practices for Language Acquisition ................................12

Deficit Language Around the Latinx Experience .......................................15

Educational Inequities and Social Reproduction .......................................17

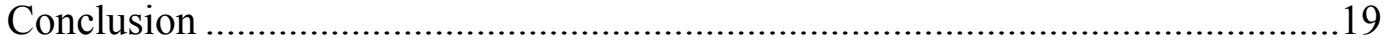

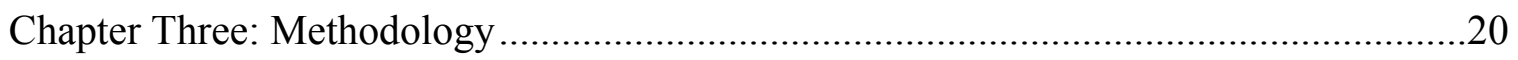

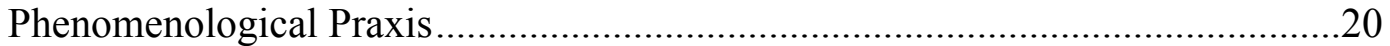

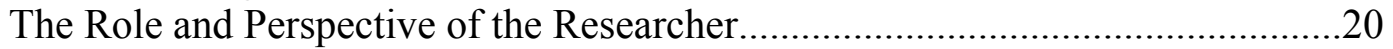

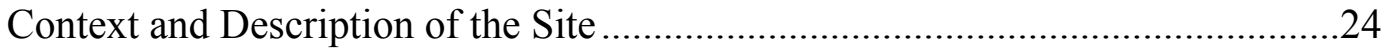

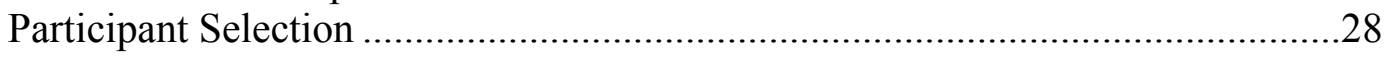

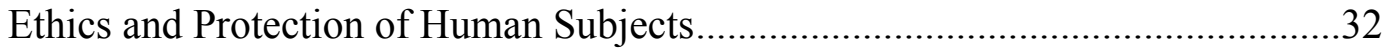

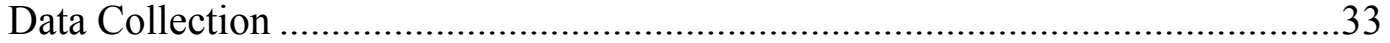

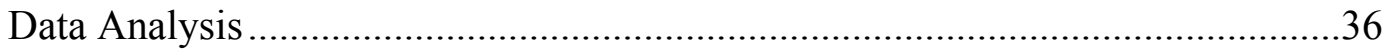

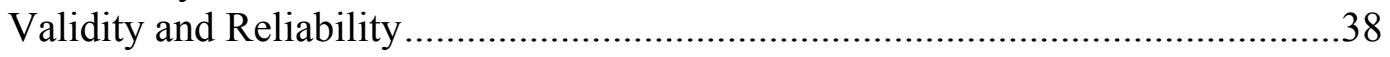

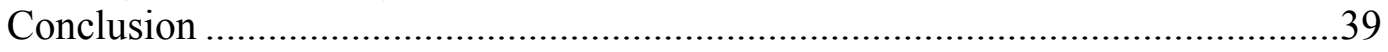

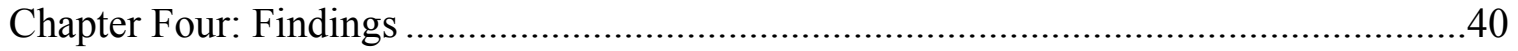

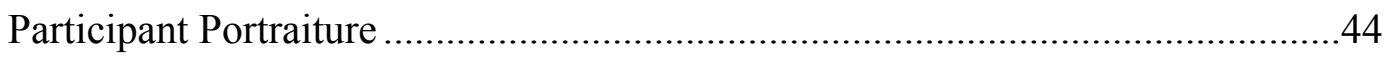


Mrs. Pfeiffer: To do Damage to the System or to the Students ...................44

Brooklyn: The Culture of Respect and Respeto.........................................46

Ivan: The Impact of Teacher Perception...................................................47

Mariah: Reproduction of Standards of Whiteness …………………….......48

Ariana: Loss of Language …………………………............................50

Key Findings ...................................................................................................5

Culture of Respect as the Foundation for Learning ..................................53

Teacher Perception of Student Ability as Defined by Best Practice ..........57

Social Reproduction: How Whiteness and Implicit Bias Show Up...........64

Summary of the Findings ...................................................................................69

Chapter Five: Discussion and Recommendations...........................................................71

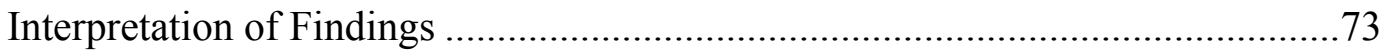

Nuances of the Culture of Respect..........................................................73

Troubling the Idea of Best Practice .........................................................75

Disrupting Social Reproduction of Schooling ..........................................76

A Response to Policy …………………………………........................77

Implications for Social Justice Leadership and Educational Equity.......................80

Implications for Policy and Practice ................................................................8

Implications for Educational Leadership ......................................................8.

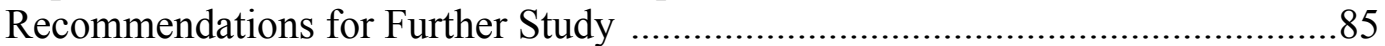

Limitations of the Study and Areas for Further Research .....................................86

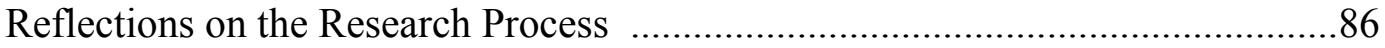

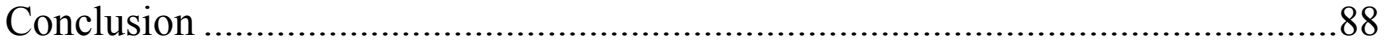

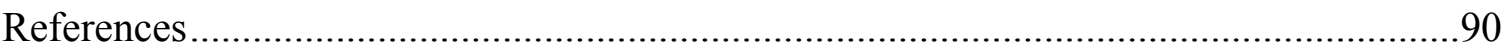




\section{LIST OF TABLES}

Table

Page

1. Teachers and the Impact of Whiteness at MacDougal Mirrors National Average ......26

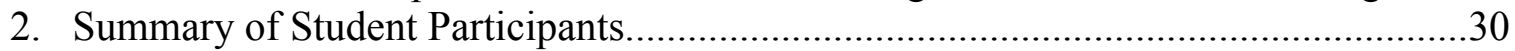

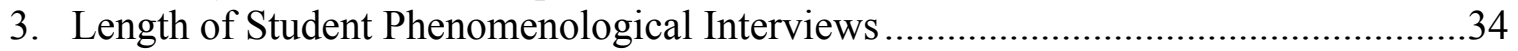

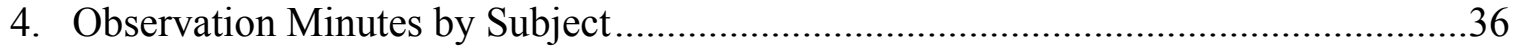

5. Classroom Observation of Instructional Minutes and Differentiation.........................42

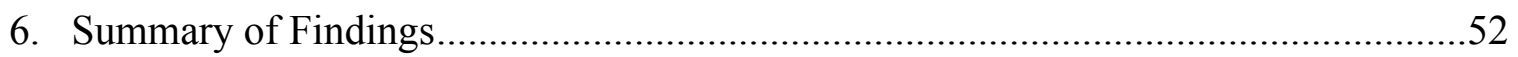




\section{LIST OF FIGURES}

$\begin{array}{lll}\text { Figure } & \text { Page }\end{array}$

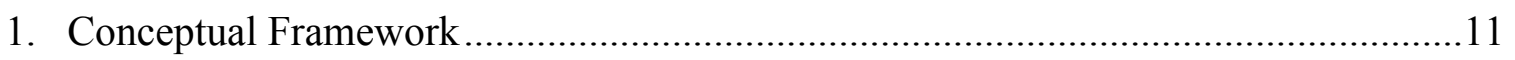

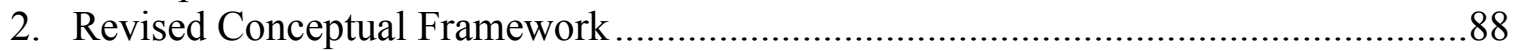




\section{LIST OF APPENDICES}

$\begin{array}{ll}\text { Appendix } & \text { Page }\end{array}$

A. Student Assent to Participate in Research ............................................................95

B. Teacher Assent to Participate in Research...............................................................96

C. Parental Permission for a Minor to Participate in Research (English) ......................98

D. Parental Permission for a Minor to Participate in Research (Spanish) .....................100

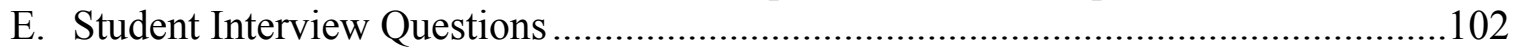

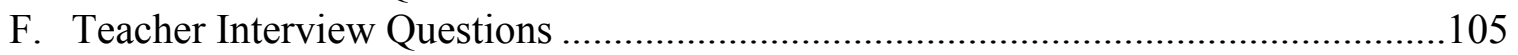

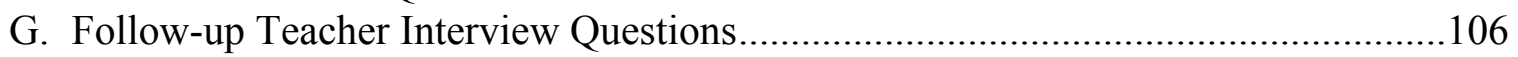

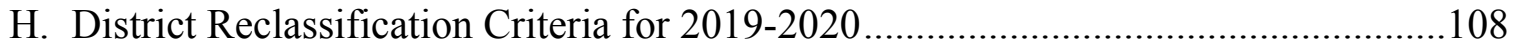




\begin{abstract}
CHAPTER ONE: INTRODUCTION
"Once social change begins, it cannot be reversed. You cannot un-educate the person who has learned how to read."
\end{abstract}

- Cesar Chavez

Institutional practices that perpetuate the tensions between a professional imperative to improve student outcomes and habitual practices that maintain institutional barriers have conditioned students to feel responsible for their own academic achievement. However, these practices have not conditioned educators to feel proportionally responsible for effective instructional practices as evidenced by improved student outcomes in the same way. These tensions are especially deep-rooted in highpoverty schools where majority-minoritized student populations, like English language learners, are inducted into their educational experiences primarily by a mostly white teaching staff. Emphasis on aesthetic care and the perception of sound instructional practices, rather than the prioritization of academic achievement as measured by student proficiency outcomes, maintains unacknowledged structural biases that promote the idea of white benevolence while masking a lack of challenging academic standards.

In an era where a progressive presidential candidate like Joe Biden can publicly proclaim that "poor kids are just as bright and just as talented as white kids," and an influential presidential advisor like Stephen Miller can be exposed through public emails as someone who harbors white nationalist beliefs and anti-immigrant ideologies, it becomes even more imperative for social justice leaders to illuminate the invisible privileges perpetually aligned with whiteness that underpin every institutional structure of 
a country founded upon the intentionally divisive social construct of race. Although we live in a time when the richest $0.1 \%$ of the American population are giving money philanthropically to solve social problems like poverty, the most predatory of the plutocratic elite are assuring that their access to policy and policymakers are upholding a system to maintain the elite class, thus monopolizing the future of America through a form of aesthetic care on a large scale. Cracks in the social safety nets have become critically apparent in the midst of this current global pandemic, when members of local neighborhoods are realizing the myriad roles schools play in sustaining the social health of communities as well as the educational attainment of its youngest members. However, the benefits that schools and teachers dispense do not excuse the harms that invisible white supremacist practices wreak upon the most vulnerable populations.

Subtlety is the new wave of embedded racist practices. Gone are the days when white supremacists dressed in hoods and burned crosses, wrote Kendi (2016) in his definitive bestseller, Stamped from the Beginning. The underpinnings of those blatant racist practices, however, are still evident and embedded in our social institutions. The social justice ramifications of continuing to implicitly and explicitly bar marginalized students from academic success cannot ignore whiteness as a central player in systemic inequalities that measure minoritized groups against a traditional white standard—-the embedded supremacy of whiteness practiced unwittingly by good-intentioned policymakers and practitioners. When scholars highlight disparities in educational and life outcomes for racialized students without naming whiteness as a primary influence, it 
projects the deficits onto those bodies as an obvious explanation for the disparities. Whiteness is rarely named as a hindering factor, even though whiteness is insinuated everywhere within the institution of education. Language classifications are an area in which ongoing systemic inequalities continue to be found, while emergent learners of English continue to be labeled and segregated into special education or remedial classrooms taught by teachers tasked with facilitating the acquisition of basic English grammar and syntax without the intentionality of facilitating the mastery of academic language or content knowledge as a foundation for future educational access.

Though I acknowledge the existence of sustained educational practices that perpetuate gaps in opportunity and access as stemming from white supremacist underpinnings, I have made the intentional choice to limit that term in the findings of this study. It is my view that addressing this topic in terms of critical whiteness and unacknowledged privilege allows the practitioners who read this research to more easily access and connect to the experiences of the participants without having to identify with a term that connotes a history of blatant racial prejudice. Scholars are also grappling with how to best draw distinctions between white supremacy and whiteness in educational research because language is important, and while attaching a more palatable term does not neutralize the negative effects of the practices, I believe it does permit a greater likelihood of inviting critical self-reflection and renewed awareness of systems. It also centers the student experience of marginalization at the forefront of this study, rather than distracting from it by qualifying the naming of the practices of their oppression. 


\section{Purpose of the Study: Asset-Based Understandings of Bilingual Students}

Existing research on educational disparities for bilingual and multilingual learners focuses on student deficiencies as measured by quantifiable assessment data, often citing perseverance as an under-developed student skill intended to be the panacea to alleviate lacks in an imperfect educational system. The purpose of this study is to analyze teacher attitudes and practices, and the residual impact of those practices on students learning English. Because there has been minimal qualitative research conducted with elementary school students, this study is intended to illuminate the nuanced experience of English learner students in an upper-elementary classroom with an experienced teacher identified as a top educator implementing strategies touted as best practices for the student population.

\section{Research Questions and Design}

The guiding questions for this research are the following: (a) What instructional and relational practices does an experienced teacher utilize that positively impact how English language learners experience core instruction? and (b) How does whiteness show up in classrooms implementing best practices for bilingual learners? The stories of the young people told through interviews speak to their compassion for the teachers tasked with improving educational outcomes, but the story told by the adults reinforces the deficits projected onto students by the practitioners identified as experts in the content knowledge, developmental benchmarks, and instructional strategies designed to bridge performance gaps. 
Though I will be using the terms English learner (EL) and reclassified fluent English proficient (RFEP) in this study to describe students who are learning English, I want to acknowledge that this phrasing is deficit framing, particularly when approaching this topic from the lens of critical whiteness. However, because I am speaking to a system that describes these students as ELs and RFEPs and for the purpose of clarity, I also will use those terms here and address the implications of a policy that dehumanizes students through the use of language and classification in Chapter Five. In terms of language classification, a student tagged as EL is identified as someone whose primary language is not English and who is not currently demonstrating proficiency in English, as measured by district criteria. An EL student is reclassified as fluent English proficient when all district criteria have been met, usually resulting in a change of instructional program.

The data collected for this study came from phenomenological interviews with students identified as either EL or RFEP. Each interview protocol was developed using standardized questions that allowed for open-ended dialog and focused on one particular aspect of their lived experience. Interview One addressed self-identity and educational history. I asked students to describe how they viewed themselves as learners and to identify times in their lives when they felt most proud of their school achievements. The purpose was to elicit experiences of success within the context of school. Interview Two centered on in-school experiences and language. During this interview I asked students if they experienced any perceived challenges, being designated as a language learner and who they attributed as supportive of their efforts. Interview Three consisted of questions 
focused on student skills and future aspirations. Using this research design, I was able to establish a relationship with each student-participant, which influenced their comfort in sharing personal stories about their lived experience through their own words.

\section{Definitions of Key Concepts}

Authentic care: Valenzuela (1999) and Duncan-Andrade (2006) argued that schools are structured around an aesthetic caring, the essence of which lies in an attention to things and ideas leading to a culture of false caring, "one where the most powerful members of the relationship define themselves as caring despite the fact that the recipients of their so-called caring do not perceive it as such (Duncan-Andrade, 2008)."

Best practice: This term applies to instructional strategies backed by evidencebased research to show validity that reinforces the practice as effective. What Works Clearinghouse, according to the American Institutes of Research, is the "leading federal source of evidence-based policies, practices and interventions that show promise for improving student outcomes" (https://ies.ed.gov/ncee/wwc). What Works Clearinghouse (WWC) was established in 2002 and is affiliated with the Institute of Education Sciences and funded by the U.S. Department of Education In order to obtain federal funding, grant writers are required to cite evidence-based best practices from WWC.

Whiteness: This term refers to the normed white cultural and social expectations, which have resulted in exclusionary deficit-based assessments of non-dominant groups

and used to maintain the status quo. Whiteness is characterized by "the unwillingness to name the contours of racism, the avoidance of identifying with a racial experience or 
group, the minimization of racist legacy, and other similar evasions" that impact other racialized groups (Frankenberg, 1993). White privilege is a side-effect of whiteness that refers to the practice of attaching more to skin-color privilege than to class, religion, ethnic status, or geographical location (McIntosh, 1988). Often unacknowledged, white privilege permeates institutions by influencing practices that further marginalize racialized groups, often classified by policies that use euphemistic parameters. Warm demander: This term was first coined by Kleinfeld (1975) to describe a classification of teachers who, through establishing rapport and trust with their students, are able to warmly demand rigorous academic outcomes. This type of teacher is characterized as having authentic care for students that translates into a reciprocal obligation to both instruct at and produce a high level of academic work because of the personal relationship.

White supremacy: Encompassing critical white theory, this term is related to the way in which our society was founded and remains organized that places white people at the top of the hierarchy of power, maintained through both explicit and implicit practices (Picower, 2009).

\section{Statement of Delimitations and Scope of Study}

Although the study's results may not be generalizable to a broad experience of English language learners, the themes illuminated here by the voices of students add to existing quantitative studies that measure achievement gaps disaggregated by language proficiency. The purpose of this study was to contribute to critical white theory as it 
relates to elementary education targeted at improving academic outcomes for English learners.

\section{Significance of the Study}

This study examined the perpetuation of deficit-based thinking and inherent bias practiced primarily by a white teacher toward her majority-minoritized students in a highpoverty school, a particular intersection that allows the projected "warmth" of the warm demander pedagogy without the "demand" of high academic standards and a critical look at effective teacher practice (Ware, 2006). The collective educational impact of unacknowledged bias projected onto groups of students tells a story about what is valued within institutions and how that translates to influence greater societal norms.

\section{Conclusion}

As instructional leaders and school managers, we are too humble about our ability to influence outcomes; instead, we need to encourage tolerance around paradigm and mindset shifts in education, never underestimating our ability to move people in the tradition of Lisa Delpit, Angela Valenzuela, and Paulo Freire toward continuous improvement of practice and tolerance for discomfort - particularly where our most underserved students are concerned. Though there may be some truth to the claim that outside influences impact school achievement, inequitable practices in schools continue to favor those already privileged by the system, and not just in terms of students. Teachers in high-poverty schools serving marginalized populations are often given the benefit of the doubt regarding their instructional best practices and efficacy in bridging 
opportunity gaps, rather than contributing to them (Oakes, 2005). This study the idea that best practices implemented broadly do not have the desired impact when the cultural context of the classroom and the community is not also taken into consideration. This study also illuminated instances of aesthetic care that, on the surface, appear to be beneficial to students. However, when examined through a lens of critical whiteness, these seemingly innocuous interactions can lead to internalized oppression by students and the social reproduction of debilitating practices, due in large part to the constraints of a traditional system that defines deficits where assets should be recognized. 


\section{CHAPTER TWO: LITERATURE REVIEW \\ "Most children are amazing critical thinkers before we silence them."}

- bell hooks

The problem statement presented in Chapter One illustrates that the academic needs of students learning English are not being effectively met by the K-12 educational system. Documented by decades of research that consistently shows achievement gaps on multiple measures of academic performance, students classified as English learners continue to be a population underserved by traditional educational practices (Menken, 2013) with few exceptions (Celedon-Pattichis \& Ramirez, 2012). Despite this expansive body of research, however, there has been little data on the student experience shared from the perspective of students. This study addressed the gaps in the literature by layering a lens of critical whiteness upon the implementation of best practices for students classified as English learners while also adding their critical voices to the existing body of research.

\section{Scope and Structure of the Review}

The literature review provides an overview of research related to the educational experience of students classified as English learners. Instructional best practices for English learners in the core subjects of mathematics and academic English were analyzed, using the lens of critical whiteness studies, in an effort to better understand and frame the experiences of students learning English as well as the systemic constraints imposed on practitioners. Because language status and privilege play a significant role in 
addressing my problem of practice, the theoretical models that guided this study were critical whiteness and social reproduction theory.

The literature builds on the conceptual framework presented in Figure 1 and is organized into the following sections: (a) best practices for English language learners, (b) the experience of schooling for Latinx students, and (c) critical whiteness and social reproduction in educational systems. In terms of my conceptual framework, I considered how critical pedagogy and best practices aligned with teacher attitudes to positively impact student outcomes within the context of systemic barriers and deficit mindset. In order to move students forward, all the component pieces need to work in coordination for collective impact.

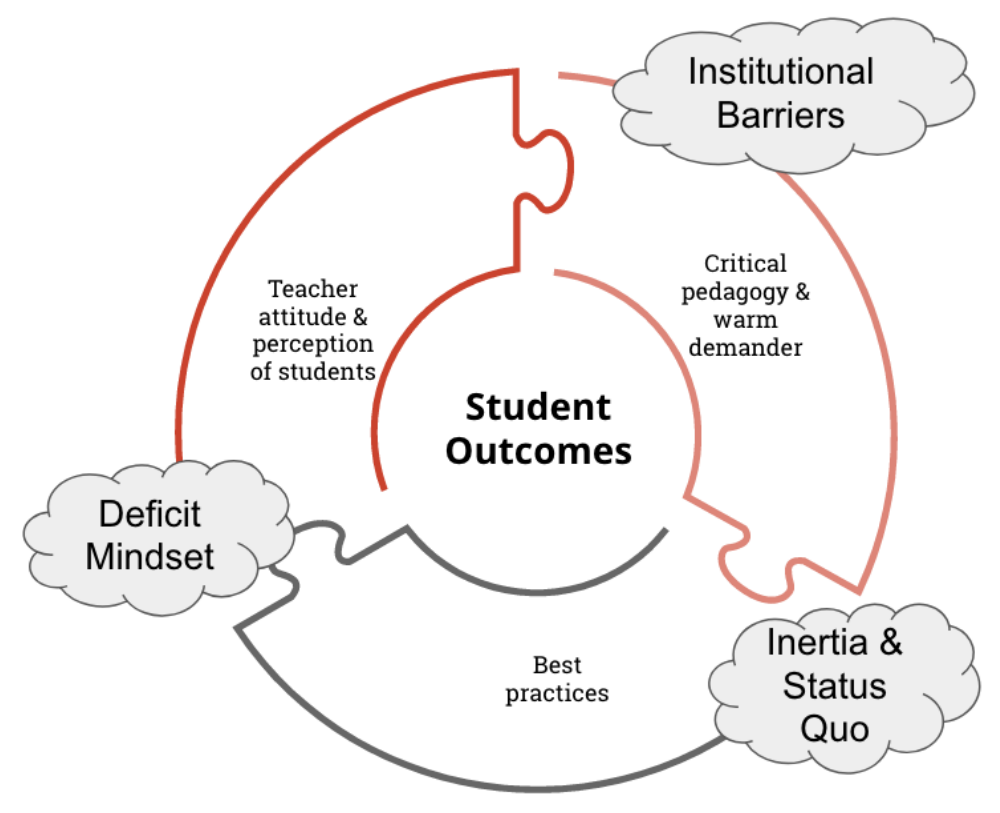

Figure 1. Conceptual Framework. 


\section{Troubling Best Practices for Language Acquisition}

Going back to the origins of linguistic study, Gee (1989) distinguished language acquisition from language learning by emphasizing the importance of primary discourse acquired in the home community of the language learner. When schools diminish these powerful first literacies, it informs students' future experiences with educational institutions that value only limited acknowledgment of learning proficiencies (Gee, 1989). Students become caught in the cross-hairs of well-intentioned bi-literacy programs and the stigmatization of not being immediately fluent in the dominant discourse. Classrooms have the capacity to provide opportunities for language learners to develop all their powerful literacies, but when learners' secondary discourse is culturally dominant and their primary discourse is seen as illegitimate, it further distances students from finding relevance in a school system that does not value the knowledges they bring (Gee, 1989). Instead, offering opportunities for multilingual students to incorporate all their language skills through translanguaging opportunities in the classroom and assemble their own meaning-making resources unbounded by distinct language confines. These translanguaging opportunities bridge perceived gaps between students learning English and monolingual students, who are already advantaged by use of their full language repertoire (Garcia \& Li, 2014). This philosophical shift would be a deviation from current practice where English language development is bounded by instructional minutes and separated based on named language. 
Issues of language learning have been the topic of research for decades; however, schools and educators have tended to operate on faulty or incomplete assumptions about ELs, language acquisition, and learning that has resulted in the continued obstruction of students learning English to thrive in content instruction (DeAraujo et al., 2018; DiCerbo et al., 2014). When examining the literature on both instructional and relational best practices for meeting the particular needs of language learners, the overarching themes fall into these general areas: increasing comprehensible input, encouraging social collaboration, relating to the real world, and providing supportive learning environments (Li, 2013; Albers \& Martinez, 2015). Several strategies that fit within this understanding of acquisition include: providing relevant contexts, connecting learning to prior knowledge and experiences, and using visual aids and physical artifacts (Li, 2013, p. 218). Haas and Gort (2009) considered not just the complex endeavor of language acquisition, but the comprehensive success of English language learners within the context of overall academic achievement and sociocultural integration. The authors further pointed out that school standards are founded on assumptions about basic literacy skill levels, academic backgrounds, and prior experiences based on norms for the mainstream, monolingual English-speaking students (Haas \& Gort, 2009). This frames the principles for constructing high-quality instruction for multilingual students around three key ideas: (a) the role of the native language in developing literacy and learning grade-level content, (b) meaning-making through culturally responsive instructional methods and curriculum, and (c) the integration of language and content. 
The English Learner Roadmap, prepared by the California Department of Education, and What Works Clearinghouse, an arm of the U.S. Department of Education, have created guidelines with suggested instructional practices that informed the creation of the new California ELA/ELD framework, aimed at improving educational outcomes for students learning English. Frameworks for instructional practice fall into the following four main areas of recommendation: (a) intentional teaching of a set of academic vocabulary words through multiple modalities across curricular content instruction; (b) integrating oral and written English language instruction into content instruction through use of graphic organizers and videos to anchor instruction to explicitly teach vocabulary while offering opportunities to extend learning of content and paired collaboration; (c) using constructive feedback on regular, structured writing opportunities to develop written langauge skills; and (d) providing small group instructional intervention to struggling students based on formative assessment and evidence of comprehension skills.

As its name indicates, these practices should shape a roadmap that lays a solid foundation for supporting English learners in achieving academic excellence; however, instructional practice is largely based on the histories, experiences, and beliefs of the practitioners tasked with successfully implementing them. Researchers in the fields of critical theory are adding to this literature base by describing the challenges facing students and teachers when so much of instruction and learning is shaped by dominant social hierarchies. 
A critical view through the lens of whiteness is necessary to move beyond best practice rhetoric in order to illuminate the continued perpetuation of inequities, even in light of these researched best practices, through a misguided belief that language and content knowledge are mutually exclusive learning endeavors, one a prerequisite for the other. Although language proficiency is related to academic performance, researchers advise that practitioners not put learning of content on hold while students acquire English proficiencies because of an unfounded assumption that these are compartmentalized experiences. Research on teaching and teacher attitudes suggests that school administrators and classroom practitioners often hold low achievement expectations for racialized students. Without interrogating the system in which so-called best practices are situated, which creates space for well-intentioned teachers to try out strategies in their classrooms without developing necessary dispositions towards learners, teacher may perpetuate implicit bias against EL students in the classroom (Banks, 2001; Ladson-Billings, 1995).

\section{Deficit Language Around the Latinx Experience}

Braudel (1958), long before Ladson-Billings (2006), argued that society must take a critical look at the debt owed within the larger context of time in order to fully understand the systemic impact of institutional and instructional practices that perpetuate disparities in educational outcomes. Though they viewed disparity through the lens of race, this also applies to language proficiency and the marginalization that non-native speakers have experienced in schools. Not a new problem on the education landscape, it 
is one that has not been adequately addressed and that continues to exacerbate the gulf between the privileged and the perpetually oppressed, as education is an early measure of life trajectory, particularly when achievement benchmarks in primary grades are endlessly unmet (DiAngelo, 2018).

Valenzuela (1999) made the case for developing relationships of authentic care through a specific component of culturally responsive teaching that values students' experiences and knowledges beyond the dominant discourse of school. Kleinfeld (1975) called it "warm demander pedagogy," defined by the idea that culturally sensitive teachers hold high expectations of academic standards for all students while simultaneously building students' self-confidence with structured support. Valenzuela (1999) named it cariño and defined it as "authentic care." Holding high expectations for students counteracts the deficit views many teachers have of students who come with gifts of language or ability that are undervalued in schools. This idea of authentic care also speaks to the current trend toward social-emotional initiatives that has become argued de facto prerequisites to academic achievement, a nuanced form of aesthetic care that hints at inherent deficits preventing students from having an ability to learn because of their perceived emotional fragility, often inferred through institutional norms as a result of early childhood trauma due to conditions of poverty.

Further emphasizing the impact of authentic, caring teacher-student rapport, Suárez-Orozco, Pimentel, and Martin (2009) explored the significance of relationships for academic engagement and achievement, specifically for newcomer immigrant youth. 
The findings of this study were consistent with previous research that suggests that positive supportive relationships are particularly important for newcomer immigrant students to bridge the gap between home and school cultures. Supportive school-based relationships prove to be the most significant factor in leading students to make greater efforts in their schoolwork, regardless of their initial English proficiencies.

\section{Educational Inequities and Social Reproduction}

White identity is a social construct that institutionalizes white supremacist values associated with maintaining that dominance by creating an unacknowledged racial hierarchy that benefits members of that group, whether they acknowledge its existence or not (Leonardo, 2002). In the United States, these values are embedded in social institutions, but are also apparent in educational institutions exhibited through practices that manifest in privileges and oppressions that reinforce stereotypical perceptions (Picower, 2009). Interactions between educators and students are influenced by these perceptions and often have negative consequences, due to preconceived beliefs which maintain low expectations and poor outcomes for racialized students. Bourdieu's (1977) theory of social reproduction initially focused on social class and class status but he connected this theory to educational settings because they so clearly maintained class standings, neutralized by an idea of meritocracy.

Yosso (2005) added to this conversation by addressing the unacknowledged cultural capital that racialized students carry with them, overlooked by the institutions that explicitly seek to maintain structural and social inequalities that benefit white people. 
Yosso (2005) bridged the interpretation of the theory of social reproduction to speak directly to educational settings by addressing knowledge as subjective. Knowledge within the context of social inequality is valued based on the normative practice of the ruling class and reproduces itself in a way that explains why the outcomes for marginalized populations are significantly lower than those of whites, who benefit from the unacknowledged privileges afforded them by the system that places them at the top of an invisible hierarchy (Yosso, 2005). When "impartial" measures are used to determine achievement and knowledge goals, it reinforces the idea that everyone has the same opportunities to attain successful outcomes. In actuality, these measures are heavily influenced by dominant white cultural norms that inherently disadvantage racialized groups.

Student identity is formed in large part from the way other people perceive them. When they internalize those perceptions projected by someone held in high esteem, like their classroom teacher, this can lead to internalized oppression. Racialized students, emergent bilinguals, and students from low-income households continue to suffer ongoing inequalities by being labeled and segregated through tracking systems that limit their access to educational rigor (Long, 2016). The systemic impact of those practices that continue to marginalize language learners within high-poverty schools based on the framework of white supremacy creates a construct within public education that failing students are failing because of the social and political consequences beyond the scope of school interventions. Meanwhile, white teachers often lack awareness of the functioning 
of racism and become complicit in viewing students in urban schools through the projection of deficit frameworks (Crowley, 2016).

\section{Conclusion}

The consequence of maintaining the status quo means we perpetuate the stigmatization of generations of students who leave school - except for the exceptions without a sense of agency or an ability to advocate for themselves and their communities. The collective educational impact of unacknowledged bias projected onto students learning English tells a story about what is valued within institutions that seamlessly influence greater societal norms. Therefore, looking at institutions through a lens of critical whiteness is a critical step in disrupting social reproduction, as is evaluating the literature on racialized populations through a lens that questions the language and quantititive measures used to define them. 


\section{CHAPTER THREE: METHODOLOGY}

"When I dare to be powerful, to use my strength in the service of my vision, then it becomes less important whether or not I am afraid."

- Audre Lorde

\section{Phenomenological Praxis and Study Overview}

The purpose of this qualitative study was to explore the classroom experience of bilingual students attending an elementary school in a predominantly Spanish-speaking community within a school district serving over 20,000 students $-66 \%$ of whom are designated as English language learners. Using a lens of critical whiteness to illuminate the impact of unacknowledged structural barriers to students who make up the majority of the campus population, this study addressed teacher practice and whether the implementation of perceived best practice had the intended outcomes for students learning English in achieving normed standards. To address the research questions, phenomenological praxis was used to identify patterns in practice meant to provide greater opportunities for English learners in accessing instructional content. This chapter provides an overview of the methods used in the research of this study (Van Manen, 2014).

\section{The Role and Perspective of the Researcher}

The myth that public education is designed as a panacea to equalize the life circumstances of marginalized students has become one of the greatest injustices perpetrated in the United States upon the largest number of citizens, and particularly noncitizens (Foucault, 1977). I have been in education for over 20 years and have seen 
repeated behaviors that marginalize students, legitimized by protocol and practice. As a social justice educator, I am concerned about the practice of labeling students as deficient when traditional teaching practices embrace neither cultural sustainability nor rigorous academic grade-level standards that students deserve. The ramifications of this shift are significant, particulary when primarily white educators situate themselves as advocates, experts, and saviors of marginalized and racialized populations.

As a white woman, I have grappled with defining my own role and positionality within this problem of practice. Upon reflecton of the arc of my professional career, my early idealism often made me complicit in unwittingly implementing institutional barriers in the name of standardization, consistency, and equality. But hindsight has tempered my early tendency toward righteousness in finding flaws in the practice of practioners, particularly in relation to this study, which is why I have taken great effort to humanize all the participants, with paticular care to the teacher. My weathered realism has compelled me to come to terms with the fact that the institution of education is significantly flawed, at odds with its professed aim of equitizing outcomes for students. With that in mind, I position myself as a practitioner balanced by scholarship, a white educator in a system normed for white privilege off-set by equity-minded activism, concentrating on altering institutional practice in order to best meet the needs of all students based on instructional impact, not perceived best practices. 
I've experienced the impact of white fragility in leadership quite significantly this year, a side-effect of the institutional whiteness that perpetuates entitlement and feelings of superiority among those in positions of authority when challenged on issues of equity that inherently disrupt the status quo. The ramifications of triggering the anxieties and insecurities that define white fragility and challenge unacknowledged institutional privilege have left residual traumas to the people directly involved in trying to disrupt marginalizing practices and gaping fissures in the collective capacity of the campus community. I've been reflective of my own role as a site leader and researcher through this process, knowing what it feels like to be devalued and dehumanized by the K-12 institution and the "leaders" who equate authority of position with infallability.

Toward the end of this study after all data had been collected, the site leader made a report to human resources that resulted in my demotion from an administrative position to a position of classroom teacher for the following school year. Whatever the transgression reported, it has never been shared with me in any capacity. Although this incident has nothing to do directly with the current study, it has been hard to ignore in light of my close reflection on leadership, whiteness, and the impact of white fragility. Being an at-will employee, there is no union protection or recourse to redress this situation, which also speaks of structural inequities that favor some voices, regardless of their legitimacy, over others. Weeks after my notification, the other site administrator in charge of the After School Program was removed from the site for "gross 
insubordination," reported by the principal, but not communicated to my fellow administrator. Neither of us were allowed an opportunity to challenge the private reports made against us. Ironically, the current principal is new to the site this year, appointed by Cabinet even though the site staff did not name her as one of the top candidates to move forward when interviews were conducted at the end of last school year. Though she claimed to be bilingual and that she had previous administrative experience, her administrative credential had not been cleared and her Spanish language skills required that she have a translator whenever there was a need to communicate with a Spanishspeaking parent.

During this same early Spring timeframe, teachers had a deadline to submit requests for transfer from the site for the following year; half of the 28 teachers requested a transfer. Nearly the entire special education team, including the school psychologist and the speech-language pathologist, requested transfers. The Spanish-speaking parent president of the School Site Council found out about both the ASP administrator's and my dismissal and requested an emergency meeting with the principal, during which she told the principal what a disappointment she was, going on to express the familial connection she felt with MacDougall Elementary, raising all of her children through its halls. This parent went to the Superintendent to express that sentiment when she realized her concerns about the rupturing of the campus morale was falling on deaf ears.

After multiple unrelated grievances to human resources went unaddressed, in March, half the tenured classified and half the tenured certificated staff signed a letter of 
no confidence and attended school board meetings to express their outrage about the actions and leadership of the principal, as well as the silent support displayed by District leadership that enabled her actions. Although I was hesitant to include this personally devastating experience in my study, it greatly informed how I thought through implications for leadership and influenced how I examined the institutional existence of unacknowledged white privilege and entitlement. Ultimately, this series of events speaks directly to the white fragility of school actors and to the institutional whiteness complicit in sustaining them regardless of documented detrimental impact on school communities.

During the research process, I remained mindful of my professional position and my personal values. Because I hold a position of authority on campus, when collecting data from both the student- and teacher-participants, I made great efforts to compartmentalize my interactions related to this study. I enlisted the support of doctoral colleagues as critical friends when analyzing data to assure that my unexamined assumptions were called into question. Their insights and questions were integral in deepening my thinking about the content of this study.

\section{Context and Description of the Site}

All research and data collection were conducted at a K-5 elementary school site, MacDougal Elementary, within the unified school district along the northern coast of California. Initially, my interest in researching the topic of improving educational outcomes for bilingual students developed while I was a site administrator at a sister school within the same district. As a site Academic Coordinator, I regularly observed 
classroom practices that focused primarily on the perceived social-emotional well-being of bilingual students through access to dimmed lighting, mindfulness videos, kinetic sand, and alternate seating configurations that removed classroom desks and chairs in place of cushions, rockers, unstable stools, and foot bands. When I initiated conversations with practitioners, suggesting that the prioritization of social-emotional well-being of students and raising expectations for academic rigor are not mutually exclusive aims, I provoked intense animosity, in word and action, from several of the teachers with the lowest levels of growth on multiple measures of assessment, all of whom were non-native Spanish-speaking "bilingual" teachers. I used quotation marks to distinguish the term bilingual, because bilingual education is a very specific framework that requires the use of a bilingual curriculum. There was no existing bilingual curriculum at the school, beyond a one-year adoption of a piloted program in the bilingual Kindergarten classrooms that was not implemented with full fidelity.

After three years at my initial site and a failed attempt at hosting a series of county-facilitated cultural humility trainings intended to initiate a conversation about how we, as practitioners, show up in classrooms with inherent privilege, especially in relation to the students served in high-poverty school settings, I requested a transfer to a different site with a similar population. Beyond the personal and professional challenges I felt with staff push-back on shifting mindset around professional responsibility, there were several other considerations that made the timing of the move appropriate in terms of this research: (a) my current site does not have a bilingual program and, therefore, it removed 
a need to critique a misnamed program as at the previous site; (b) my current site employed teachers with more than five years of experience at the highest grade levels with greater potential for asset-based framing of teacher practice; and (c) the new site provided a fresh opportunity to come in as a more objective researcher without preconceived ideas about teachers or their practices and without previously established relationships with student or teacher participants.

Table 1

Teachers and the Impact of Whiteness at MacDougal Mirrors National Average

\begin{tabular}{|c|c|c|c|c|}
\hline Grade & \multicolumn{2}{|c|}{ English-Only Speaking Teachers } & \multicolumn{2}{c|}{ Native Spanish-Speaking Teachers } \\
\hline & $\begin{array}{c}\text { Less than 2 years } \\
\text { experience }\end{array}$ & $\begin{array}{c}\text { More than 2 years } \\
\text { experience }\end{array}$ & $\begin{array}{c}\text { Less than 2 years } \\
\text { experience }\end{array}$ & $\begin{array}{c}\text { More than 2 years } \\
\text { experience }\end{array}$ \\
\hline Kinder & 1 & 2 & & 1 \\
\hline First & & 2 & & 2 \\
\hline Second & 1 & 2 & 1 & 1 (long-term sub, \\
\hline Third & & 2 & & 1 \\
\hline Fourth & 2 & 2 & & \\
\hline Fifth & & 3 & & \\
\hline
\end{tabular}

Note. $81 \%$ of staff are English-only speakers, on a campus with over $78 \%$ ELs. This closely mirrors the NCES data from the most recent $2015-16$ study showing $80 \%$ of public elementary and secondary school teachers identify as white.

The racial make-up of the teaching staff both within the district and at my research site is significant, particularly when considering the disparities in outcomes for historically marginalized and "othered" student populations. Table 1 is a depiction of 
MacDougal Elementary, but is also reflective of the majority of the 25 regular education sites within the district. According to the National Center for Education Statistics (NCES), "Having a teacher of the same race/ethnicity can have positive impacts on a student's attitudes, motivation, and achievement and minority teachers may have more positive expectations for minority students' achievement than nonminority teachers" (NCES.ed.gov; Ladson-Billings, 2006).

Leading scholars in the field of urban education have been urging white teachers to critically examine their positionality in relation to the students they teach for decades (Ladson-Billings, 2006; Tatum 1997; Valenzuela, 1999). Picower (2009), a prominent scholar in critical whiteness studies who derived from the early work of Critical Race Theory, expounded on the ramification that the "sheer number of White people in the teaching field in a country marked by racial inequality has implications for the role White teachers play in creating patterns of racial achievement and opportunity” (p 197-198). This is especially true in districts and schools that serve a high percentage of racialized students.

The school district for this study served 16 elementary schools, six junior high or middle schools, and three comprehensive high schools. There were an additional four alternative schools and four charter schools. The site at which this research was conducted had a population of 551 students, 523 of whom identified as Latinx and 430 who were designated as English learners (78\%). Thirty-nine percent of this population of 430 were long-term ELs (LTELS), meaning they had not demonstrated English 
proficiency after four to five years of instruction in school. Just $6 \%$ of the campus population was designated as RFEP. When compared to the district population overall, serving 20,106 students, $66 \%$ of whom were classified as English learners (including recent RFEPs), the site exceeded the district average for language learners. Therefore, the topic of this study was particularly relevant to the setting.

\section{Participant Selection}

Because I wanted to amplify student voices, I began my recruitment knowing I wanted to be in a fourth or fifth grade classroom, believing I would be more likely to elicit feedback from older students. Unbeknownst to me at the time of my recruitment, the most aggressively hostile teacher at my previous site had been a mentor teacher to the recommended teacher-participant that the previous administration suggested I recruit at my current site. She was completing a semester of student teaching in a third Grade classroom at that site over six years ago. This came up in a conversation prior to our interview. On the fourth grade team, all four teachers were white women but just two had more than five years' experience. One was recently credentialed and the other was still completing coursework. The fifth grade team was identified as one of the "strongest" teams on campus by the previous site administrators and though all three of the teachers were white women with at least five years of teaching experience, I initially only approached the teacher who became my participant for two reasons: (a) she was recommended by both the previous principal, who retired prior to the beginning of the 2019-2020 school year, and the academic coordinator I replaced; and (b) she is the grade- 
level lead on the site Leadership committee with administrative experience in the After School Program. Because she agreed to participate, I did not make further inquiries.

The teacher-participant, Mrs. Pfeiffer, had taught for seven years, all at the research site, and was a tenured member of the staff. She had experience in both fourth and fifth grades because of a year of looping with the same cohort of students. She attained an administrative credential the previous year and was anxious to clear that credential with site experience as a school administrator. She was proud of her investment in the school community and her proximity to campus. Though she was ethnically white, because she had a Latinx husband and two children with him, she selfidentified as Mexican. When the topic of race came up, she said, "We're Mexican," referring to herself and her family.

To facilitate student participant recruitment, I sent home letters to every student in the participating classroom, in both Spanish and English, informing parents of my research parameters. I also co-presented with the teacher briefly during Back to School Night to meet with parents and be available for questions. Of the 26 students in the class, 14 returned permission slips, and of those 14, all but two met the criteria of being classified as either EL or RFEP. Eight girls and four boys made up my final focal group, but one of the girls classified as an English learner opted out of further interviews after our first interaction because she felt self-conscious about her language abilities. The only experience each student-participant had with education was within this central coast school district, though two were born in Mexico. 
This classroom did not necessarily mirror the campus make-up, as there was a much higher percentage of RFEP students in this class than average; however, it makes sense that students in fifth grade would have a higher than average English proficiency on a K-5 campus. Of the 26 students enrolled, 15 were classified as EL, seven had previously been reclassified as fluent English proficient, and four were designated as English only speakers. Six students, four EL and two EO, received special education services in the form of pull-out for RSP. Broken down by percentage, $58 \%$ of the class had the language status of EL (15 students), with an additional 27\% designated as RFEP (7 students), and 15\% English only (4 students). Every designated RFEP student returned a permission slip for participation.

On average, each student was interviewed three times over a three-week period for an average of 16 minutes. A summary of the students interviewed is included below. Table 2

\section{Summary of Student Participants}

\begin{tabular}{|l|l|l|l|l|}
\hline & Pseudonym & Age & Gender & Language Status \\
\hline S1 & Mariah & 11 & F & RFEP (in 1st Grade) \\
\hline S2 & Marina & 11 & F & RFEP (in 1st Grade) \\
\hline S3 & Sofi & 10 & F & EL (Level 2) \\
\hline S4 & Alex & 10 & M & EL (Level 3) \\
\hline S5 & Juliana & 10 & F & $\begin{array}{l}\text { EL (Level 2) } \\
\text { participated in Interview 1 only }\end{array}$ \\
\hline S6 & Brooklyn & 10 & F & RFEP (in 4th Grade) \\
\hline
\end{tabular}




\begin{tabular}{|c|c|c|c|c|}
\hline & Pseudonym & Age & Gender & Language Status \\
\hline $\mathrm{S}_{7}$ & Mark & 10 & $\mathrm{M}$ & RFEP (in 3rd Grade) \\
\hline S8 & Mia & 10 & $F$ & RFEP (in 3rd Grade) \\
\hline S9 & Ivan & 11 & $\mathrm{M}$ & EL (Level 2) \\
\hline S10 & Lissette & 10 & $\mathrm{~F}$ & RFEP (in 1st Grade) \\
\hline $\mathrm{S}_{11}$ & Robbie & 11 & $\mathrm{M}$ & RFEP (in 1st Grade) \\
\hline $\mathrm{S}_{12}$ & Ariana & 10 & $F$ & EL (Level 2) \& SPED \\
\hline
\end{tabular}

Note. The student-participants in the study, who each chose their own pseudonym, closely mirror the campus composition for language status. EL Level refers to the most recent ELPAC scores from 1 to 4.

The district guidelines for reclassification require that students score at Level 4 overall on the most recent assessment of the annual ELPAC, based on grade-level cut scores set by the state. Students must also demonstrate grade level proficiencies using the district-adopted NWEA MAP scores for either Reading or Math, the previous year's state CAASPP Language Arts or Math scores, and satisfactory class grades on reports of progress. Parental input is another consideration. Four years of monitoring for all reclassified students is a requirement to make sure that students learning English do not slip in academic progress when scaffolds for English language development are removed. For a full examination of the reclassification criteria, see the table in Appendix H.

Though lower ELPAC scores indicate low-emergent English language acquisition and potentially newcomer status, all students in this study had attended only schools within this district since enrolling in Kindergarten. Newcomer status is attached to 
students new to the United States within the past 12 months. That was not the case for the English learners in this study. These students could more accurately be categorized as long-term English learners as part of the $39 \%$ of the EL population mentioned earlier who had not demonstrated English proficiency after four or five years of school instruction.

\section{Ethics and Protection of Human Subjects}

To ensure that ethical principles were observed during this study, a full IRB protocol was submitted and approved both by the university and the school district. The potential risk to privacy was expressed to the teacher-participant, parents of participating students and student-participants. The risk was minimized by conducting interviews individually and in a private setting without the risk of being overheard. Pseudonyms were used and data were shared only with members of my committee and a limited number of critical colleagues.

The potential loss of privacy for the teacher-participant is greatest, because she is the only teacher involved in this study and her identity could easily be determined. She was given a full debriefing of the purpose of the study, however, and consented to participate. Her potential for discomfort in reading the findings and analysis of this study was also greatest, as they might portray her in a way that she did not anticipate. Because of my own position of privilege and authority as a researcher and administrator on this site, my intention in presenting this data and in alleviating discomfort is to hold appreciation at the center of my critical lens and to evaluate the data with a focus on humanizing all participants. 


\section{Data Collection}

During this research study, classroom observations, student interviews, and teacher interviews were conducted. The teacher interviews and classroom observations were intended to play a secondary role to student voice. I conducted an IRB-approved pilot study with a focus group at my previous site during Spring semester and developed themes for the student interviews based on the data that came from that interaction. Because the initial teacher interview was brimming with unanticipated responses, that data played a more significant role than initially intended. I used student reflections and classroom observations to further unpack and analyze the content of those responses.

The student interviews followed a phenomenological approach, with three distinct rounds of semi-structured interviews spread over three interview sessions. The series of interviews took place over the course of three weeks. As a new member to the site, this approach allowed me to develop rapport with students rather quickly. All interviews were conducted outside on a picnic bench near the classroom when weather permitted, or in the cafeteria when it was raining. Both areas were accessible to students during their unstructured time on campus and neither space was affiliated with me as a site administrator or with the main office. This was an intentional choice in my attempt to recognize the power differential between the participants and me, and a way to put students at ease in a familiar setting. All interviews were digitally audio recorded. Each round of interviews was transcribed by the researcher prior to the next round of interviews. Interview One focused on student identity and self-perception. Interview Two 
focused on language in the educational setting. This interview attempted to gauge how students viewed teacher perception of their language proficiency in relation to the rigor of instruction. Interview Three focused on future aspirations and attributions.

Table 3

Length of Student Phenomenological Interviews

\begin{tabular}{|c|c|c|c|c|}
\hline Pseudonym & Interview 1 & Interview 2 & Interview 3 & Total Minutes \\
\hline Mariah & $\begin{array}{l}9 / 17 / 19 \\
6: 46\end{array}$ & $\begin{array}{l}9 / 19 / 19 \\
3: 11\end{array}$ & $\begin{array}{l}10 / 3 / 19 \\
9: 46\end{array}$ & 19:43 \\
\hline Marina & $\begin{array}{l}9 / 17 / 19 \\
11: 08\end{array}$ & $\begin{array}{l}9 / 20 / 19 \\
2: 56\end{array}$ & $\begin{array}{l}10 / 3 / 19 \\
6: 39\end{array}$ & $20: 43$ \\
\hline Sofi & $\begin{array}{l}9 / 17 / 19 \\
7: 07\end{array}$ & $\begin{array}{l}9 / 19 / 19 \\
4: 14\end{array}$ & $\begin{array}{l}10 / 3 / 19 \\
8: 30\end{array}$ & 19:51 \\
\hline Alex & $\begin{array}{l}9 / 17 / 19 \\
4: 18\end{array}$ & $\begin{array}{l}9 / 1920 \\
2: 14\end{array}$ & $\begin{array}{l}10 / 3 / 19 \\
4: 28\end{array}$ & 11:00 \\
\hline Juliana & $\begin{array}{l}9 / 17 / 19 \\
5: 32\end{array}$ & - & - & $5: 32$ \\
\hline Brooklyn & $\begin{array}{l}9 / 17 / 19 \\
4: 57\end{array}$ & $\begin{array}{l}9 / 19 / 19 \\
3: 53\end{array}$ & $\begin{array}{l}10 / 4 / 19 \\
5: 08\end{array}$ & $13: 58$ \\
\hline Mark & $\begin{array}{l}9 / 17 / 19 \\
7: 00\end{array}$ & $\begin{array}{l}9 / 19 / 19 \\
2: 19\end{array}$ & $\begin{array}{l}10 / 9 / 19 \\
2: 54\end{array}$ & $12: 13$ \\
\hline Mia & $\begin{array}{l}9 / 17 / 19 \\
8: 49\end{array}$ & $\begin{array}{l}9 / 19 / 19 \\
2: 08\end{array}$ & $\begin{array}{l}10 / 9 / 19 \\
4: 23\end{array}$ & $15: 20$ \\
\hline Ivan & $\begin{array}{l}9 / 17 / 19 \\
5: 30\end{array}$ & $\begin{array}{l}9 / 19 / 19 \\
2: 37\end{array}$ & $\begin{array}{l}10 / 4 / 19 \\
3: 42\end{array}$ & 11:49 \\
\hline Lissette & \begin{tabular}{|l|}
$9 / 17 / 19$ \\
$9: 50$
\end{tabular} & $\begin{array}{l}9 / 19 / 19 \\
5: 38\end{array}$ & $\begin{array}{l}10 / 3 / 19 \\
4: 20\end{array}$ & 19:48 \\
\hline Robbie & $\begin{array}{l}9 / 18 / 19 \\
3: 36\end{array}$ & $\begin{array}{l}9 / 19 / 19 \\
2: 45\end{array}$ & $\begin{array}{l}10 / 4 / 19 \\
4: 01\end{array}$ & $10: 22$ \\
\hline
\end{tabular}




\begin{tabular}{|l|l|l|l|l|}
\hline \multirow{2}{*}{ Pseudonym } & Interview 1 & Interview 2 & Interview 3 & Total Minutes \\
\hline \multirow{2}{*}{ Ariana } & $9 / 18 / 19$ & $9 / 19 / 198$ & $10 / 4 / 19$ & \\
\hline
\end{tabular}

Note. The length of time spent with each student broken down by interview topic.

I did not follow the phenomenological approach with the teacher interview, instead opting for a structured dialog shortly after starting my classroom observations but before conducting any student interviews. At this initial interview, I gave the teacher a journal, suggesting but not requiring that she use it to reflect on her own experience of this process; she did not use it for this purpose. We scheduled a follow-up meeting after data collection to debrief the process; however, we were interrupted by the principal and never rescheduled. Instead, the teacher agreed to respond to some of my follow-up questions on a shared document to clarify the context of what was said or observed in the interview or during observations.

The length of the teacher interview was 46 minutes. I conducted 31 observations over 52 school days from late August to early November. I spent a total of 24 hours in the classroom, the duration of each observation ranging from 10 to 105 minutes. I took realtime notes during each observation and wrote data memos after a short series of observations. The goal of the classroom visits was to both observe teacher practice and provide context to the teacher and student interviews, and to establish a consistent presence for students in order to develop a level of comfort. 
Table 4

Observation Minutes by Subject

\begin{tabular}{|c|c|c|}
\hline Subject & Times Observed & Total Minutes \\
\hline Math & 20 & 637 minutes \\
\hline Reading & 14 & 442 minutes \\
\hline Writing & 4 & 176 minutes \\
\hline Other & 8 & 190 minutes \\
\hline
\end{tabular}

Note. Though I attempted to observe all subjects, the class schedule did not always reflect the actual instruction at the times listed.

In addition to this formal data collection, the principal and I informally attended one grade-level collaboration to share initial assessment data. Because a few of the comments made by two of the three teachers were so egregious, I made note of them and they further informed my context for analysis. On rare occasions, copies of class assignments were also collected.

\section{Data Analysis}

All student interviews and the teacher interview were digitally audio-recorded and transcribed by me, and included notations for long pauses, incidents of nervous laughter and other informal speech patterns. This offered deeper meaning to some of the responses when I was in the process of coding. Field notes were typed for each observation and organized chronologically by date in a digital spreadsheet. Reflective journal entries and data memos were written during data collection and analysis. Achievement data and 
previous teacher comments on student cumulative files were also collected for context and baseline information.

The first cycle of coding was done informally during transcription of interviews. Because this process is iterative, the first round also involved the more formal re-reading of transcripts to highlight key words and phrases in vivo. Process coding was used in the first cycle of reviewing observation data.

Process coding is the use of gerunds in defining actions. This form of coding was used for the second cycle of interview coding to find patterns in routines, rituals, rules, roles, and relationships (Saldana, 2016). Finding patterns of behavior and instances of intentional relational interactions between teacher and students, and implementation of teaching practices intended to scaffold ELs, supported the further analysis of these practices and behaviors. Descriptive coding was used as a second cycle for observation data, meaning descriptive terms were used to highlight observed instances of teacher practice and student engagement. Sometimes these descriptive terms came directly from what the speaker said, but because coding is interpretive, often they were condensed (Saldana, 2016).

The two cycles of coding led to the emergence of five concepts that then got filtered down to three themes, each showing the mot number of data points during coding. During this process, critical friends and committee members were enlisted to make sure my own biases were held in check and not unintentionally skewing my interpretations. 
And in telling their stories, I relied on the use of portraiture. Portraiture, as described by Lawrence-Lightfoot (2016), is a phenomenological methodology that marries the empirical description of participants with the aestheticism of qualitative narrative traditions. It is distinct from other methodologies in that it focuses on humanizing the people depicted by documenting their strengths, resiliencies, and value within the context of a study, rather than pathologizing and blaming them based on the quantitative data used to describe them (Lawrence-Lightfoot, 1997).Portraits of the participants were created from the narratives they shared with me and from other collected data from cumulative folders that featured attributes previous teachers noted, and their self-identified traits. I acknowledge, however, that these depictions have been created within the confines of a limited interaction with each of them and may only frame an identity for them in relation to this study.

\section{Validity and Reliability}

All interview protocols were reviewed by my committee and their feedback incorporated prior to the start of my data collection. The same protocols were used with all students for all three rounds of interviews. Two cycles of coding were conducted for interviews and teacher interview data was triangulated with the student interviews and observation data from the classroom. Because parents were not included in my original IRB, I did not elicit feedback from them about how they viewed the school and instruction in relation to language proficiency and academic outcomes for their students, however, I did have occasion to speak with colleagues and friends about their own early 
educational experiences as language learners to make sure I was catching the nuances of how othering and inclusion take space in academic settings.

To increase the reliability of this study, researcher positionality has been articulated and revisited throughout in an attempt to address biases. Although the sample was not random and did not directly mirror the overall campus make-up, it is representative of a fifth grade experience in a school setting with a similar demographic make-up.

\section{Conclusion}

In this chapter, I discussed my methodology for this study. Data was taken primarily from the teacher interview and triangulated with classroom observation and a student interviews, supported by field notes and reflective journaling. This study sought to bridge gaps in literature related to the ramifications of how unaddressed bias and whiteness show up in classrooms, impacting young students from historically marginalized communities, even as evidence of best practice implementation is demonstrated. 


\section{CHAPTER FOUR: FINDINGS}

"I'm trying to learn Spanish again because when I was little I knew, like, a lot of Spanish but now I don't for some reason."

- Robbie, 5th Grade

This qualitative study was guided by two research questions: (1) What instructional and relational practices does an experienced teacher utilize that positively impact how students learning English experience core instruction? and (2) How does whiteness show up in a classroom implementing best practices for bilingual learners? Using critical whiteness, this study's purpose was to examine engagement strategies implemented by an effective classroom teacher to identify practices that support language acquisition and access to grade-level content in a school with a statistically significant percentage of English learners.

Quantitative measures of student achievement have shown that public schools in the United States are not adequately addressing the gaps in achievement for language learners and other minoritized student populations and have not been for decades. Studies from the National Assessment of Educational Progress (NAEP) further contended that reading scores continue to go down in American schools for all students, widening the gap particularly for those who come to school without the benefit of being native speakers of the dominant discourse (NCES.ed.gov). This case study offered a qualitative layer of understanding of the challenges expressed by an educator and experienced by students in a school within a district in a region of the state of California where this dilemma is replicated over and over for racialized students who do not meet minimum 
scores of proficiency, as measured by inequitable educational systems that are not designed for equitable outcomes or democratic ideals.

This study used phenomenological interviews to examine the experiences of English learners and reclassified fluent English speakers in an effort to validate and substantiate student voice within an educational institution that often yokes them with deficit ideations about who they are based on one aspect of their identities: language.

This chapter offers a portrait of the teacher-participant and of four representative students, though additional student voices will be included. Findings based on the triangulated data came from all three data points: teacher interviews, student interviews, and classroom observations. I completed over 24 hours of classroom observations, conducted three-rounds of interviews with 12 students, and conducted one in-person interview with a follow-up online interaction with the teacher-participant. Table 5 shows a breakdown of observed teaching practices intended to support ELs. Though some of these practices align with literature on best practices for this group, many of them are just generally good teaching strategies. It should be noted, however, that the amount of teacher-directed instruction made up only a small fraction of observation minutes, especially in comparison to the amount of independent time students were afforded utilizing digital devices. This phenomena offers insight into how Mrs. Pfeiffer organizes her classroom and will inform the way she is portrayed in the next section. 
Table 5

Classroom Observation of Instructional Minutes and Differentiation

\begin{tabular}{|c|c|c|c|c|c|}
\hline Math & $\begin{array}{l}\text { Times } \\
\text { Observed }\end{array}$ & Total Minutes & $\begin{array}{l}\text { Observed Teaching Practices } \\
\text { Intended to Support ELs }\end{array}$ & $\begin{array}{l}\text { Individual } \\
\text { Chromebook Use }\end{array}$ & $\begin{array}{l}\text { Whole Class } \\
\text { Video/Tech Use }\end{array}$ \\
\hline $\begin{array}{l}\text { Bridges } \\
\text { Instruction }\end{array}$ & 5 & 206 & Modeling whole class & & \\
\hline $\begin{array}{l}\text { Not Bridges } \\
\text { Instruction }\end{array}$ & 3 & 74 & $\begin{array}{l}\text { Contextualizing math problems; } \\
\text { partner sharing; defining terms; } \\
\text { use of alliteration }\end{array}$ & & \\
\hline ST Math & 10 & 245 & Differentiated lessons & 10 & \\
\hline Khan Academy & 1 & 45 (overlap) & Differentiated lessons & 1 & \\
\hline $\begin{array}{l}\text { Not Bridges } \\
\text { Assessment }\end{array}$ & 1 & 67 & & & \\
\hline $\begin{array}{l}\text { Totals } \\
\text { Observed }\end{array}$ & 20 & $\begin{array}{c}637 \text { minutes } \\
(10 \mathrm{hrs} .37 \\
\text { min })\end{array}$ & $\begin{array}{l}\text { Of } 637 \text { minutes observed, } 290 \\
\text { minutes students were working } \\
\text { independently on computers } \\
\text { and another } 67 \text { minutes was } \\
\text { spent on a teacher-created } \\
\text { assessment }\end{array}$ & 11 & 0 \\
\hline Reading & $\begin{array}{l}\text { Times } \\
\text { Observed }\end{array}$ & Total Minutes & $\begin{array}{l}\text { Observed Teaching Practices } \\
\text { Intended to Support ELs }\end{array}$ & $\begin{array}{l}\text { Individual } \\
\text { Chromebook Use }\end{array}$ & $\begin{array}{l}\text { Whole Class } \\
\text { Video/Tech Use }\end{array}$ \\
\hline Class Novel & 4 & 163 & $\begin{array}{l}\text { Graphic organizer; opportunities } \\
\text { to write }\end{array}$ & & \\
\hline Epic Books & 6 & 189 & $\begin{array}{l}\text { Audio for different modalities; } \\
\text { prediction; partner share }\end{array}$ & & 6 \\
\hline $\begin{array}{c}\text { AR/Independe } \\
\text { nt }\end{array}$ & 3 & 45 & & 1 & \\
\hline ReadWorks & 1 & 45 (overlap) & & 1 & \\
\hline $\begin{array}{l}\text { Totals } \\
\text { Observed }\end{array}$ & 14 & $\begin{array}{l}442 \text { minutes } \\
\text { (7 hrs. } 22 \\
\text { min) }\end{array}$ & $\begin{array}{l}\text { Of } 442 \text { minutes observed, } 279 \\
\text { minutes students were working } \\
\text { independently on computers } \\
\text { and another } 45 \text { minutes was } \\
\text { spent independently reading }\end{array}$ & 2 & 6 \\
\hline
\end{tabular}




\begin{tabular}{|c|c|c|c|c|c|}
\hline Writing & $\begin{array}{c}\text { Times } \\
\text { Observed }\end{array}$ & Total Minutes & $\begin{array}{l}\text { Observed Teaching Practices } \\
\text { Intended to Support ELs }\end{array}$ & $\begin{array}{l}\text { Individual } \\
\text { Chromebook Use }\end{array}$ & $\begin{array}{l}\text { Whole Class } \\
\text { Video/Tech Use }\end{array}$ \\
\hline Note-taking & 3 & 116 & Note-taking & 1 & 1 \\
\hline $\begin{array}{l}\text { Summarize } \\
\text { Reading }\end{array}$ & 1 & 60 & Summarizing & & \\
\hline $\begin{array}{l}\text { Totals } \\
\text { Observed }\end{array}$ & 4 & $\begin{array}{l}176 \text { minutes } \\
(2 \mathrm{hrs} .56 \\
\text { min) }\end{array}$ & $\begin{array}{l}\text { Of } 176 \text { minutes observed, none } \\
\text { was spent on writing practice }\end{array}$ & 1 & 1 \\
\hline Other & $\begin{array}{l}\text { Times } \\
\text { Observed }\end{array}$ & Total Minutes & $\begin{array}{l}\text { Observed Teaching Practices } \\
\text { Intended to Support ELs }\end{array}$ & $\begin{array}{l}\text { Individual } \\
\text { Chromebook Use }\end{array}$ & $\begin{array}{l}\text { Whole Class } \\
\text { Video/Tech Use }\end{array}$ \\
\hline ELD & 1 & 20 & $\begin{array}{l}\text { Equity sticks; gradual release, } \\
\text { think time, checking for } \\
\text { understanding, spot-checking, } \\
\text { timer }\end{array}$ & & \\
\hline WIN & 1 & 20 & $\begin{array}{l}\text { Scaffolded differentiated } \\
\text { reading groups, leveled } \\
\text { computer program }\end{array}$ & 1 & \\
\hline $\begin{array}{c}\text { Door } \\
\text { Decorating }\end{array}$ & 1 & 12 & & 1 & \\
\hline Library & 2 & 29 & & & \\
\hline Science videos & 2 & 80 & & & 2 \\
\hline 9/11 Video & 1 & 29 & & & 1 \\
\hline $\begin{array}{c}\text { Totals } \\
\text { Observed }\end{array}$ & 8 & $\begin{array}{l}190 \text { minutes } \\
\text { (3 hrs. } 10 \\
\text { min) }\end{array}$ & $\begin{array}{l}\text { Of } 190 \text { minutes observed, there } \\
\text { was just } 20 \text { minutes of direct } \\
\text { instruction }\end{array}$ & 1 & 3 \\
\hline
\end{tabular}

Note. This table shows the breakdown of how many observations were done in specific subjects and components of those subjects, as well as how often technology use and instructional practices were implemented.

Through this data collection, three key findings emerged: (a) how a culture of respect improves performance outcomes for ELs and improves critical self-reflection by practitioners, (b) how teacher perception of student capability is influenced by assumptions that best practices are replicable to all students who fit a particular 
demographic, and (c) how social reproduction and external pressures to achieve illuminate how implicit bias and whiteness show up in educational institutions.

\section{Participant Portraiture}

As described in Chapter Three, portraiture provides another opportunity for researcher positionality to be reflected upon and contextualized in a way that humanizes the participants and helps to create a more complex understanding of their perceptions and experiences within the confines of this study. Though other participant voices will be highlighted throughout this chapter, each of the students I chose for portraiture create a representative sample of students who expressed a range of ideas that came out of student interviews and will be attached to a particular theme that came from collective data. What follows are short aesthetic portraits that attempt to capture the nuances of each participant's characters within the context of the research setting, framed by their own words.

\section{Mrs. Pfeiffer: To do Damage to the System or to the Students}

The experienced classroom teacher, Mrs. Pfeiffer, taught fifth grade at MacDougal Elementary for her entire career so far of seven years. She was recognized and recommended by previous site administrators as being the "best teacher" on campus. She expressed an easy willingness to participate in this study as a way of reflecting on her own classroom practice, and with an eye toward moving into an administrative role in the near future. After five years of teaching, she enrolled in an administrative credentialing program with that objective in mind. Mrs. Pfeiffer expressed an understanding of how 
professional growth and promotion are advanced through collegial connections with influential colleagues, and indicated her strong desire to take a greater role in campus leadership. She participated as a grade-level representative on the campus leadership committee, meeting with other grade level leads and site administrators to address the needs of the campus. She also took a leadership role in supporting the Positive Behavior Interventions and Supports (PBIS) initiatives on campus and maintained a pseudoadministrative role one day a week in the After School Program.

Mrs. Pfeiffer lived with her family in a home just a mile and a half away from MacDougal Elementary. She explained her relentless commitment to the school community, knowing her young children will eventually attend MacDougal, and hoping she will one day be its principal. In our early interview, she grappled with framing the school community as both a safe space and an impediment to her personal growth: "I can't really picture myself going to any other school, but that's also just my bubble. I don't have any other experience at another school which is probably what makes it a scary idea to leave."

Throughout my interactions with Mrs. Pfeiffer, she revealed the tensions she contended with in her chosen profession, particularly around the changing expectations of what her job entailed, balancing effective instruction with the demands of new programs and policies, and balancing previous accolades on her practice with recent trends in achievement data, stating the following: 
There's a lot of pressure on test scores when you get to the upper grades and these kids don't perform well on tests... I try not to let it bother me but it's difficult. You get beat down after so many years of trying so many things and the test scores hardly ever move.

She recognized the limitations of her own experience within one school setting but also sought to positively impact student outcomes. She shifted between distancing herself from the experience she had in the classroom with expressing great vulnerability at having her identity tied to student data and how that was reflective of her practice, not knowing what to do to have a greater impact.

\section{Brooklyn: The Culture of Respect and Respeto}

At the beginning of her fourth grade year, 10-year-old Brooklyn was redesignated as a fluent English speaker. She attributed her success in school to the support of her family and her own hard work, paying attention to teachers and avoiding distractions. She valued her school experience because of supportive interactions she's had with teachers and friendships she's developed with classmates. Her previous teachers described her as "eager to learn, bright, and well-behaved" with "supportive parents."

The concept of respect grounded in the culture of family was manifested in this

exchange when I asked who in her life has been most supportive of her academic success, to which she replied,

My big brother. And all my teachers. My teachers have been really supportive since I speak Spanish. I really wanted to learn English and they've always been supportive of me. But (my brother) always corrected me and would always help me with homework and would always read to me. I speak more English now and when I go home and I have to communicate with my parents, just like, people who don't know English. It's kind of hard for me remembering Spanish. It's a 
challenge. I really don't... I ask my big brother if he knows the word I'm trying to think of.

Though Brooklyn identified her teachers as supportive, her emphasis on the ongoing support she received from her brother speaks to the familial cultural wealth that carries with her. Valenzuela (1999) argued that cultural and familial respeto emphasized in the home, however, can morph into a sense of powerlessness within the school classroom, making students feel like they are not entitled to self-advocacy and are only valued in relation to their conformity to the dominant language norms and cultural expectations. This interaction illustrates the strands of teacher relationship and the impact of family influence on student perceptions on the theme of respect.

\section{Ivan: The Impact of Teacher Perception}

Ivan was an 11-year-old English learner who described himself as athletic. He mostly liked school because of the social and physical interactions he had during organized sports and highlighted the recognition he had gotten for extracurricular nonacademic achievements. He credited his classmates for helping him when he struggled with computerized math practice and said that speaking English continued to be a challenge for him. Previous teachers described him as "chatty and social," requiring repeated "redirection and monitoring."

When we talked about the challenges of being a learner of English, Ivan said, "When I read something in English it's hard for me to read. In Spanish, the same. To just learn a word and then you have to switch to another [language]." On the subject of 
academics, he said his teachers have been "nice," but when asked who helped him the most, he named his classmates, Will and Alex, "because when I'm in struggles, like in a math problem, they help me." Though Ivan was at MacDougal since enrolling in kindergarten, his language proficiency seemed to have created a barrier to his relational interactions with teachers. He repeatedly redirected the academic conversations to PE and recesses with his friends, and when I asked him to tell me about a time he felt proud of himself in school he took a long pause and replied, "I forgot." Ivan's insights illuminate the strand of teacher perception of student capability defined by the theme of best practice.

\section{Mariah: Reproduction of Standards of Whiteness}

In first grade, both Mariah and her twin sister, Marina, were reclassified as fluent English proficient. They were both high-achieving and valued their friend group for the supportive academic competitions they engaged in to improve their individual performances. Mariah recognized the influence of her older sister, of whom she was very proud as impacting her own academic achievements. Mariah described herself as kind and "useful," and she appreciated the kindnesses of her teachers above all other qualities. Previous teachers described Mariah as having a tendency toward being "bossy." One teacher wrote on her cumulative record that Mariah needs to learn how to "own it" when she does "something wrong," and also to "MYOB," or mind your own business.

Mariah was one of the top achievers in class, precocious and confident when working on assignments, and always willing to support classmates who might need 
additional direction. I asked her to explain why she was so engaged in school and she told me the following:

I like to write. A lot. I was the first... instead of learning Spanish first, I learned English first because I would hear my brother and my sister talk in English so I got more engaged in English when I was a little girl. When I was in 1st Grade I passed my language test and I was very amazed in myself... I didn't think I was going to pass it.

I followed up with a question about who she thought most contributed to her success in achieving good grades and acquiring language. Her response was the following:

My parents had teached me a lot through the way and my sister had helped me with my homework and stuff. She'd teach me and I'd go do it by myself. (My mom) reads in English and in Spanish but either way she's not really — she's an English language learner but she doesn't know English that much but she understands what I'm saying.

Mariah classified her mother as an English language learner. This spoke directly to what she had been exposed to during her young career, absorbing and regurgitating the primary goal that schools with high populations of students classified as EL have of elevating the acquisition of English above other skills like critical thinking, collaborative engagement, effective communication such as writing, and kindness. This short interaction also reveal the primacy that many non-dominant-language-speaking families place on acquiring English proficiency, even when it becomes a barrier to fluent dialog in the primary language of the family. Mariah's excerpt speaks to the internalized oppression students can experience, as defined by the theme of social reproduction. 


\section{Ariana: Loss of Language}

At 10-years-old, Ariana was very much her own person. She expressed a particular pride in participating in this study, because she wanted to share her experience for posterity. She recognized her own struggles with reading, but credited the librarian and her teachers for supporting her English acquisition and improved reading comprehension. She shared a lesson from her padrino, reminding her that she needed to value the language of her parents, because being able to speak to them in their shared language is important. Ariana, like many of the students in this study, expressed concern over "losing" her primary language, particularly when communicating at home with her Spanish-speaking family. Previous teachers described Ariana as a "leader who enjoys bossing peers around," and as someone who was "immature" and had "difficulty working with others."

Ariana shared a story about the complexity of acquiring a new language while maintaining her primary language:

My dad says - no my dad and my mom say 'try your best every day.' And in 4th Grade my brother helped me and my dad helped me sometimes when my brothers didn't want to help me. They (my family) said I used to speak only Spanish. And now they teach me more English... but I'm starting to remember (Spanish) because my mom and all of my family members talk in Spanish but my brother and my dad - my two brothers and my dad and me speak English. My mom doesn't.

When she does not know a word in Spanish, I asked what strategies she relied on.

Ariana said, 
My brothers are usually around. I tell them 'how do you say this word in Spanish to my mom' and they figure it out and they just help me. If they're not there, my mom kind of knows it so I explain it, what it is, and I tell her the word because sometimes she knows it and sometimes she doesn't.

The unintended consequence of learning the dominant language has conspicuous consequences for family relationships. Ariana's experience with language speaks to the social reproduction that happens in schools that priortizie the dominant discourse.

Together, these students anchor my findings by connecting their own experiences to observable practices in the classroom and teacher insight on what matters most in impacting student experience in this particular school setting.

\section{Key Findings}

The findings are organized initially by what came out of the teacher interview, corroborated by observation data and student experience. Findings fall into three broad themes. The first theme is the definition and function of respect in situ. Within this theme, strands related to positive teacher relationships, family influence, and humanizing relational practices in the classroom were revealed during interviews and observations. The second theme is the local definition and implementation of best practices. Within this theme are strands related to teacher perception of student capability and assumptions about the replication of best practices. The final theme is social reproduction and external pressures to achieve. Within this theme, which is heavily influenced by the first two, strands related to how implicit bias and unacknowledged whiteness show up in classrooms with EL students, how teacher experience shapes teacher practice, and how 
students' definitions of what it means to be good at school may be evidence of internalized oppression, when viewed through a lens of critical whiteness. Table 6 graphically depicts themes and their accompanying strands. The top row highlights what came up primarily from observation data. The middle row shows what came from teacher interviews in large part, and the bottom row speaks most closely of student experience as shared in their own words.

Table 6

Summary of Findings

Best Practices: Tensions between Intention and Outcome

\begin{tabular}{|l|l|l|}
\hline Respect & Best Practice & Social Reproduction \\
\hline Positive Teacher Relationships & $\begin{array}{l}\text { Teacher perception of student } \\
\text { capability }\end{array}$ & $\begin{array}{l}\text { Implicit Bias and } \\
\text { Unacknowledged Whiteness }\end{array}$ \\
\hline Family Influence & $\begin{array}{l}\text { Assumptions about the } \\
\text { replication of best practices }\end{array}$ & $\begin{array}{l}\text { Teacher Experience Shapes } \\
\text { Teacher Practice }\end{array}$ \\
\hline $\begin{array}{l}\text { Humanizing Instructional } \\
\text { Practices }\end{array}$ & $\begin{array}{l}\text { Teacher is helpful/Friends are } \\
\text { helpful }\end{array}$ & $\begin{array}{l}\text { Students Internalize their own } \\
\text { oppression }\end{array}$ \\
\hline
\end{tabular}

Note. Findings are organized into three broad themes with supporting strands. The first theme is respect. The second theme is best practice. The third theme is social reproduction. The top row defines what came from observation data. The middle and bottom rows detail what came from the teacher and student interviews.

Each theme is defined in terms of what came out of the collective data. In an effort to validate and legitimize student voice, quotes from portraitured and other students will illustrate and develop each strand more fully. Integration between various strands in the findings close out the chapter. 


\section{Culture of Respect as the Foundation for Learning}

"I think just making sure that they (students) feel successful is the important thing... I see the biggest improvement with them when you're (sic.) able to make them feel like they're succeeding."

- Ms. Pfieffer

"(What's made me successful is)... working hard. My parents, they never really had the job that they wanted and they always gave me the best. And I just really appreciate that so I always try my best at school."

- Brooklyn, Age 10, RFEP in fourth grade

The first theme that emerged centered on relationships built on the foundation of respect. All student participants expressed positive early experiences in school, and the stories they shared primarily focused on the kindnesses and empathetic expressions of their previous and current teachers and administrators. Nearly every participant told me their teachers were "nice" and that they viewed themselves as "good students" because they were well-behaved, cooperative, and compliant to classroom norms and expectations. When asked to explain why she thought her school was a good school, Brooklyn elaborated: "All the teachers are really nice and I have a lot of friends and they treat you really good. This is a really good school." Other students described MacDougal as "the best place" because "just the people there." Alex pointed out that teachers are "respectful to the students." Mark, a boy who described himself as "very quiet, respectful, and most of the time just sit-in-the-back kind of person" credited his family for instilling in him the belief that school is a place to be "respectful, and don't be mean to anyone." 
As these student descriptions illustrate, there was a strong foundation in respect instilled in their collective upbringing. They brought these familial and cultural understandings of respect to their school experiences and interpreted classroom interactions in terms of relational dynamics emulated by their families. Being "nice" is interpreted as a byproduct of respect, and so students believe themselves to be "good" when they behave in ways they interpret as respectful, or "nice," and they value their teachers above all else for their kindnesses. In my role as the site English Language Advisory Committee (ELAC) facilitator, my conversations and interactions with parents strongly support the understanding that sending students to school grounded in a foundation of respect will enable their children to learn everything they need to be successful.

Observations of the classroom exemplify the teacher's implementation of relational and instructional practices that scaffold students and provide opportunities for successful outcomes. Clearly, classroom expectations had been established before I started conducting observations, and patterns of behavior were evident in the repeated opportunities the teacher provided for students to successfully transition between instructional tasks after explicit directions and ample time were provided. Humanizing practices allowing for students to feel successful and relational practices that built bonds between individuals and the teacher certainly shaped the way the classroom functioned in a positive way. Mrs. Pfeiffer relied on the communal understanding of respect, too, particularly in rare instances of frustration. Once, she announced to me as I entered a 
quiet classroom that "they aren't being very respectful today." I noted that every student in the room was sufficiently compliant and silently reading at their desks. Another time when we all entered together after morning recess, she appeared flustered said to students, "When you come in as I try to get things situated, you're supposed to be quiet." After a few minutes, "If you've written your prediction [for a Mystery Doug science video], what should you be doing? Reading silently is the answer." Students readily complied immediately after this directive.

Ironically, the need for patience was a concept that came up several times in the teacher interview. Ms. Pfeiffer expressed the following philosophy:

[The] focus for the last few years has been, not so worried about all the standards that they learn but just if I can at least spark an interest in learning before they go to middle school. I feel like middle school and high school is when things click better... kids are ready to learn more. Where, in my opinion, if we could just teach them good habits, good ways to treat each other, to learn, to understand how to do research on your own and how to educate yourself... then they're going to be great adults and they're going to do great on the next step.

This expression of what she thought students needed most could be interpreted as Mrs. Pfeiffer's definition of what respect meant in her relationships with students. She saw herself as laying the foundation for future learning by modeling and exhibiting care and kindness and opportunities for students to feel success so that they would be prepared for academic gains in secondary schools.

From my analysis of classroom practice, Mrs. Pfieffer rarely shared personal stories about herself; however, one memorable moment was an attempt to connect with 
students during a math lesson by sharing her own struggles with "being bad at math." When her dad would help her with math problems, she said, he was not patient.

I'm patient because that's my job. Let's say my dad would help me and I was going too fast and he would get really mad and (say) that I'm making stupid mistakes. He was frustrated. Because I made that one mistake, I got the whole problem wrong. I'm a teacher so I don't say 'stupid' but I say 'silly' mistake. You probably knew the right answer but you wrote the wrong number. So now when I say "silly" mistake, you'll know what I mean. It's the hardest part of teaching, how to teach something so easy to someone who doesn't know it.

While the intention behind sharing this story was to relate to students struggling with new math concepts, the deficit language used had an undertone that could be internalized by students already struggling with academic content.

When viewed through a lens of critical whiteness, this is an example of the gradation of dominant ideology underpinning a white teacher's perceptions of the capability of students struggling with an instructional concept she is tasked with imparting. The subtlety with which this experienced and highly regarded teacher uses to deflect responsibility for that task by humanizing her own experience while at the same time demeaning students is what critical whiteness theorists would describe as unacknowledged whiteness revealing itself in institutional and social ways that appear to have nothing to do with race. Privileges, ideologies, and stereotypes reinforce institutional hierarchies and the larger system of white supremacy within our social systems, most especially traditional systems like education (Picower, 2009).

Taken together, these strands illuminate the powerful connection of respect that students, families, and the teacher point to in building relationships as a foundation for 
future academic success. The undercurrent of the unacknowledged perception of students as deficient layered upon this foundation of trust and relationship, however, put teachers in the dichotomous position of being the facilitators of building strong bonds reminiscent of students' family connections, and concurrently finding opportunities to point out their shortcomings. These messages coming from a trusted and respected mentor can lead to internalized oppression by students who experience academic struggle.

In the next section, the theme of teacher perception and the implemented best practice is explored.

\section{Teacher Perception of Student Ability as Defined by Best Practice}

"We're throwing everything we have up against the wall and hoping that something sticks and works."

- Mrs. Pfieffer

"Well... I feel bad for them (bilingual students) because I really want them to know English but I honestly don't know how to help with that... I don't really know why but I feel a little bad for myself."

In this section, I discuss how teacher perceptions of students are largely based on the idea that best practices learned in pre-service programs to specifically address the needs of ELs are problematic on multiple levels, not least of which is the significant disparity in people of color as practitioners, researchers, and instructors of these practices, being that the majority of both the K-12 teaching profession and professors in pre-service programs continue to be white. My observations of the classroom offered opportunities to highlight instances of implemented practices that were intended to 
provide scaffolded access to content for ELs, but their implementation alone did not equate to improvements in student performance.

The most prominent example of a best practice observed in the classroom was the use of technology in the form of Chromebooks to differentiate learning objectives based on student ability. Programs like ST Math, Lexia, and Accelerated Reader have been shown to support student progress when implemented with fidelity, however, the critical component of teacher intervention and oversight of these programs is often missing. In this classroom, for example, I spent over 30 hours in observation and experienced less than three-and-a-half hours of teacher-led instruction using a district-adopted curriculum, but nearly 10 hours of students working independently on differentiated computer programs with minimal teacher intervention. This breakdown is disaggregated in Table 5 . When asked about the use of curriculum in her classroom, Mrs. Pfeiffer described the Math program, Bridges, as her "nemesis," arguing,

Bridges and Number Corner is very conceptual. It requires intense understanding of [my students'] number sense. This year specifically I don't feel like my students are there. I think it's really important that the other grade levels on campus teach it because it builds on itself, but then in 5th grade when the students are still unable to solve it... I just want them to know how to solve math problems.

When the district licensed ST Math three years ago, the directive was clearly and repeated messaged in private district email communications to all site teachers and administrators implementing the program. The stated intent was to utilize the program as a component of a two- or three-part rotation so that teachers could work with small groups of students on scaffolded or enriched lessons while the rest of the class worked at 
their own pace on ST Math. Though my analysis of classroom time spent with ST Math versus other math instruction show this was not the case in Mrs. In Pfeiffer's class, she strongly defended her use of whole-class ST Math, arguing that she was using it as recommended by the program. Students, Mrs. Pfeiffer said, would struggle indefinitely on ST Math levels if she were working with a small group, unable to be interrupted, thus reinforcing wrong practice. Allowing students to approach her when they came to a challenge, she could scaffold in-the-moment as the program promotes, she defended. According to the literature shared by ST Math and disseminated by district curriculum leaders, teacher oversight is the recommendation of the program, and students in fifth grade are encouraged to work for 80 minutes a week on ST Math. In Mrs. Pfeiffer's class, students easily doubled that amount, with 30-40 minutes spent daily on individual practice, which begs the question, what is differentiated computerized practice providing for students learning English when it's devoid of language and meaningful teacher feedback?

In a follow up online interaction, I asked Mrs. Pfeiffer to elaborate on her philosophy about student engagement based on the implementation of best practices for ELs, like repetition and note-taking during math instruction. She responded,

When students ask for help I will never help them until they have shown me that they have reviewed their notes and have written it out and are trying to do it. In the real world we don't have to memorize anything, we just have to know how to find the answers and where to look. Plus students with learning deficits and language barriers need to be able to go back and have reminders to review. And also it goes back to the forms of language. They hear me say it, they see me write 
it and then they feel their hands writing it as they are seeing it again on their paper as they write it.

Though attempting to instill an independent work ethic, the nuanced relationships the teacher has with students based on proficiencies further marginalizes those students most likely to struggle with instructional content when they are discouraged from asking for help when they need it. When looking at this idea of work ethic through critical whiteness, the silence on the part of the teacher in "never" helping without the prerequisite effort or on the part of the student in not asking for help becomes an active choice of empowerment or disempowerment that on its surface seems to fairly align to ideals of meritocracy (Yoon, 2018). This is, however, a subtle power differential that has lasting ramifications for disempowered populations.

Another example of how a strong bond between students and teachers and use of best practice and small group scaffolding can unintentionally morph into a practice of internalized academic self-consciousness for students was shared by Lissette. She viewed herself as someone not "good at math," and rather than acknowledge her own dedicated efforts to improve, she offered gratitude to her teacher for patience.

Lissette pointed to being pulled out of PE class by her fourth grade teacher as a major contributor to her success in tackling math facts.

I was not that good in math at the beginning of 4th grade and my mom bought me some flashcards to practice at home. I would also stay sometimes in PE with Ms. A and a little group in the back... and Ms. A helped me a lot... She had a lot of patience with me when I didn't get it. Even if I had to repeat it, like, three times, she would always - every single time I said, "Can you repeat it again?" - she would always repeat it. 
Lissette is one of the highest achieving students in class. She consistently falls into the top of the class in reading level (as measured by the Accelerated Reader STAR test) and at or above grade-level on Northwest Evaluation Association Measures of Academic Progress (NWEA MAP) testing in both Reading and Math. Lissette is an active member of Student Leadership, a participant in the campus Green Team, and a student who was reclassified English proficient in first grade. There is very little at which she does not excel; yet, she credits her teacher as a major player in that equation.

Mia was another outstanding student who consistently performs at or above grade-level on multiple measures of performance. Raised by a single mother in the United States, she was born in Mexico and has lived within this school community for four years. She said, "My mom works in the fields and my uncle also works in the fields and my dad's in Mexico." Her third grade teacher made an impression on her because Ms. T mediated a misunderstanding between Mia and a friend.

She talked to me... and said, "You don't have to get upset for that and I'll talk to him." So, I feel like when I've been sad — because I got my grades down a bit she said... "Your grades have gone down" and then she helped me with that so I feel that's why [she has been an influential teacher].

Mia cried earlier this year when her reading level stayed stagnant. Mrs. Pfeiffer sent her to me to explain why it is harder to show continued growth when a student like her is already achieving well beyond grade-level proficiencies. Mia's illumination of this story points to the fact that she appreciated being seen and validated by her teacher in helping her tackle a relational misunderstanding with a classmate. Ms. T's criticism of 
her grades declining didn’t register to Mia, a perpetually high-achieving student, as a deficit view of her performance but instead as an offer of support to bring them up.

A common theme among high-achieving students when discussing influential people who supported their academic success was the individual attention they received from teachers. Students appreciated teachers who they perceived as holding high expectations for them and for the unique opportunities they were given for differentiated learning. Students classified as English Learners did not share stories like this with me; instead, they often credited classmates and family members for support in completing class assignments and homework. Beyond the examples of familial and peer support shared in excerpts of Ivan and Ariana, the other three EL-classified participants, when asked about what engaged them most in school work and learning, noted weekly visits to the school library, practice time on ST Math, and unstructured time with classmates. Lissette told me that she was afraid to ask for help at school, saying, "I don't like to talk when other people talk. I get nervous. Right now when I was on ST Math I was struggling." When I asked Alex why MacDougal was a good school for learning, he responded, "There's a lot of people that you could talk to. There's a lot of kids that you could be friends with." This speaks to his own prioritized values of relational engagement. When I pressed about specific instances of academic engagement, he shared that reading books and completing all levels of the computerized phonics program, Lexia, had done the most to make him feel like he was learning. 
This pattern of unintentionally omitting references to the teacher when sharing stories of classroom engagement spoke volumes about the way unobtrusive practices of implicit bias can further alienate students already on the fringes of dominant culture because of language proficiency. Implemented best practices geared specifically toward ELs did not reap intended benefits academically or relationally in this classroom where respect and compliance are at the foundation. This was further illustrated by my interaction with Sofi:

I like school so much. I don't know, 5th Grade just changed it all. I got a really nice teacher. I had trouble in 4th Grade, like with multiplication, subtracting. (But) I'm getting really good... It's a really nice school.

When I asked her if she would describe herself as a good student, she told me the following:

In my opinion, I think that I am, but other than that, I don't know. I got better, a little better at some stuff. I just don't know if I'm a good student or not because I don't know other people's opinions.

I asked her who most influenced her progress in school. She said, "My mom. She really is always - she really wants me to really try hard on school, and my dad, too. And my teachers, they want me to try and try harder [than] what I have done in 4th grade." The stories of high-achieving RFEP students attributing their successful academic achievements in large part to supportive teachers was in stark contrast to the personal responsibility EL students expressed about the need to try harder and of being afraid to ask for help, highlighting again the power differential based on dominant language proficiencies. This may come across initially as a case of individual effort. Mia, who 
worked harder by missing P.E., deserved the achievement and relational benefits she got, while Sofi continued to struggle because of her perceived deficits, which were perceived by herself and presumably implied by her teacher. Viewed through the lens of critical whiteness, however, the stories of Mia and of Sofi illuminate how teachers are able to perpetuate the myth of American meritocracy without taking stock of their own awareness, or critical consciousness around issues of race, privilege, power, and oppression in order to be successful with students of diverse needs and talents (Picower, 2009).

\section{Social Reproduction: How Whiteness and Implicit Bias Show Up}

"(My biggest challenge with EL students) is the learning gap. I think that's really challenging. You never know: how far down do I go? Especially when at the end of the year I'm going to test you on 5th grade standards, you know. And... as far as the EL side of it, how much scaffolding do I do for language before I'm just scaffolding the standard too much? Like, now I've spoon fed you when I was just trying to support your language deficit."

- Mrs. Pfieffer

No, (I don't face challenges being bilingual) in school. At my house sometimes I don't know how to say some words in Spanish, though. I get confused.

- Alex, Age 10, EL

Well, sometimes (I face challenges being bilingual) because one time I went with my padrino and he said that everything you need to know - everything in Spanish - you need to start talking in Spanish because not everything is going to be in English and you need to learn more Spanish because that's what your parents talk and that's important."

- Ariana, Age 10, EL

"I feel like I'm doing great - I'm right on my grade limit and I am on 5th grade reading so I do feel like I am successful because not too many people are there right now, so I'm really glad. I think I've learned some good things because when I was in 1st, I really didn't know how to speak much English. I was just an English learner."

- Marina, Age 11, RFEP 
Though the importance placed on the concept of respect was observed and articulated throughout this study, I wanted to trouble the idea that best practices have the intended outcomes when implemented, even within an environment where trust and relationship had been established. The way things appeared in the data analysis, these well-intentioned and highly promoted practices actually align with the very institutional barriers that social justice and equity educators are attempting to disrupt.

While interviewing Mrs. Pfeiffer, there were multiple contradictions that came up. There was a clear understanding of what was supposed to be happening in the classroom to bridge opportunity gaps; however, there were also very definite tensions around how to actually bring those practices to fruition. Teaching is a unique profession that apprentices practitioners from an early age, when we all start school for the very first time. Those early experiences shape the trajectory of who we become as educators and how we interact with students. For many, the idea of disrupting a system that is so familiar, though flawed, is easy to excuse away because it requires imagining something that has never existed. Inequitable systems do not create equitable results, which is why it is imperative for social justice and equity practitioners to transform the way we initiate students into their educational careers and how we mirror their strengths back to them throughout. This is especially true for white teachers who make up the majority of the teaching staff in K-12 education so that people of color are not the sole holders and healters of the traumas of this imperfect system. 
Ms. Pfeiffer shared a story that exemplified this unintended replication of past marginalizing practices. When I asked her to share one of her biggest successes as a teacher, she recalled a story about a group of formerly fourth-grade students that she inherited in fifth grade who were

terrible to their teacher, like ran her out of the school, she cried every day. (It was the) worst group possible. And all the teachers sat in the staff room all year stroking this teacher's ego about how the kids were unteachable. It's not her fault, it's the kids; they're terrible kids... It's my biggest pet peeve when people talk shit on kids. I was so tired of it I told (the administrator), "I want that entire group.' She was like, 'Uh, are you sure we shouldn't move some of them?" and I was like, 'No, I want the whole class because I want to show those teachers that (sic.) just sat there on their asses talking crap.

I cried every night. It was the worst thing I'd ever been through... Then slowly I became a drill sergeant. I took everything away... like no birthday parties, none of this, none of that, nothing at all. I had an emotionally disturbed kid who was throwing stuff at me every day and I walked out of the room one day with (the yard supervisor) and I called the office and said I needed help and it was the day my aunt was having a double-mastectomy — I had not told the students anything about this.

He was talking to a student in my class who had had cancer when he was a little boy and I said something like, "Stop interrupting me" and he just looked me in the eyes in front of the whole class and said, "You don't give a shit about cancer. You don't care about people who have cancer." And this was the day she (my aunt) was having her surgery. This kid was so psychotic I still can't get over it to this day. He was like, "You are the spawn of the devil and you will burn in hell..."

I told (the administrator), "I will never be in this room alone with him ever again..." Anyway, he got moved out, things started to shift in the class and it was like the best class I've ever had. No other class is ever going to top how much I loved those kids. And my husband told me one of the days I was going home and crying, 'cause I'm not mean. But I had to be mean. So I was, like, going home exhausted because I was like, faking it all day long. Like, no fun at all. Like, "Okay, put away your books. Get out the next book. Open up to this page. Okay let's go, you have 30 seconds I'm getting started now." Like, I didn't even, I had zero leeway to even be like, "How was your weekend?" Nothing with these kids, 
and at recess I was like, “Out!” and I locked the door and didn't let any of them even come in. I had to put that boundary up that I couldn't trust them because they were so bad to me that I couldn't like, put my boundary down to even be cool with them.

And he (my husband) told me, "It's not your job to make them learn anything. It's just your job to teach them. You just need to go to work and you just need to do your job and then you come home. Who cares if they learn anything. Who cares if they do anything. Like, that's not your job. That's someone else's job. Like, that's their parents' job, that's their whatever, like that's someone else's job to make them learn. It's just your job to go and teach them every day." And I've like, kept that, "okay, that makes sense." And I've kept that with me when you (sic.) have that, like one or two kids that (sic.) is just so hard and doesn't like, won't do anything to like, let it go. Like, let them not do anything. Don't let your classroom be ran (sic.) by that one or two kids who - you're not going to change them. Like, they've already decided the way that they want to be the whole year. All you can do is just help the rest of them, like continue to learn.

This extended portion of the interview with Mrs. Pfieffer illustrated the tensions she grappled with of wanting to positively impact students previously viewed through a deficit lens, while reverting to viewing them through a deficit lens herself without the reflective experience of realizing she's doing it. When analyzed through the overlay of critical whiteness, a story of a hero teacher overcoming adversity looks more like a case of a teacher replicating the school-to-prison pipeline, having the "problem" removed from her jurisdiction, enabling her to love the compliant students who remained, none of whom are mentioned in the story of her biggest success.

This was not what I expected to hear when asking about a successful experience, and when reading through the transcript, it was hard to pinpoint which part of the incident sticks out to her as overwhelmingly positive when so much of it is retold through a deficiency lens. In fact, it could be justifiably argued that this incident is a campus 
replication of carceral practices that so many marginalized students experience as they are pushed out of traditional school settings. This "emotionally disturbed," "psychotic" student likely most needed the implementation of best practices and the consistency of the classroom culture of respect and the addition of therapeutic supports. Not to discount that one child could have a huge negative impact on a class, I could not help but wonder if reaching out to share her own struggle with having a family member undergoing cancer surgery might have diverted this incident and offered instead a humanizing moment for both teacher and student to connect on a common feeling of helplessness and personal pain.

Seeing students as human beings and not as test scores is another concept that came up repeatedly in the teacher interview. The idea that test scores are not reflective of student ability is one side of the coin that excuses both teachers and students from meeting proficiency cut scores. It also, though, speaks to the blind spot of institutions to continually emphasize local and state assessments as objective measures of ability without taking in the context of what it means to create and perpetuate an academic achievement gap that reinforces the idea of marginalized group inferiority. Kendi pointed to an even more sinister implication of using statistical measures for achievement gaps, asserting that disparities in achievement can then be portrayed as accurately reflecting disparities in intelligence (Kendi, 2019, p. 101). Mrs. Pfeiffer said she did not look at previous assessment data or language designation for her students because 
I don't feel like it matters. I feel like even the ones that have reclassified and even the ones that are EOs - you have EOs who are in the red on everything, SBAC (Smarter Balanced Assessment Consortium), MAP. I've kind of realized that a lot of them are in the same struggle whether they just got here from Mexico last year and have very little English or have spoken it their whole lives and only know Spanish because they're in school with Spanish speakers.

While on the surface this could be interpreted as a humanizing approach to getting to know students individually rather than by number, she lumped them all into a monolithic group anyway, comparing them based on their lack of proficiencies with the dominant language.

Through the use of language centered on describing and categorizing students, we can see the tensions resting within practitioners tasked with making measurable change within a system that resists impactful change. How teachers experience these dynamic tensions shape the way they show up for students, in their beliefs and in their instruction. When these teachers make up a majority white teaching staff, it becomes even more imperative that we consider how the "tools of Whiteness" are designed to protect and maintain dominant and stereotypical understandings of race (Jupp, Berry, \& Lensmire, 2016; Picower, 2009).

\section{Summary of the Findings}

The three themes of respect, implementation of best practice, and social reproduction capture the experiences of participants within the context of this school community in this fifth-grade classroom and address the study's research questions about 
how instructional and relational practices impact English learners and how unacknowledged whiteness shows up in classrooms with racialized student populations.

The data suggest that a culture of respect is foundational for relationships of trust to foster academic preparation and achievement. The findings also indicate that the second theme, the implementation of best practices, is problematic when the outcomes of implementation are not reflected in improved measures. These two themes combined reveal how the third theme of social reproduction perpetuates what has always been done within the traditional institution that is K-12 education. The findings presented here demonstrate the importance of developing respectful relationships while disrupting the system of social reproduction for marginalized students like those learning English. Recommendations to disrupt the status quo are presented in Chapter Five. 


\section{CHAPTER FIVE: DISCUSSION AND RECOMMENDATIONS}

'It's not their fault. I am not sure what 'it' is but I think that it could be their lack of background knowledge, language, experience, structure, discipline, closed mindedness. They are kids who are being raised by different types of families. I think what I try to do

is to try my best to teach them what they need to know, be a role model of proper language, give them experiences through reading, videos, field trips. I definitely give them structure and discipline. I teach them when certain behaviors are appropriate and when they are not. And lastly, I try to keep myself informed on world events based on facts and not personal opinions."

- Mrs. Pfeiffer

This study sought to deepen our understanding of the experiences of students learning English in a school dominated by white educators within a classroom where the culture of respect is perceptible, but variable, depending on perceived proficiency of students. The narratives of youth participants, in their own words, position us to the entry points of transformation and disruption of institutional practices that construct barriers to equity and of the mindsets that perpetuate them. Many of the narratives constructed by students, when viewed from the perspective of a critical whiteness researcher, illuminate opportunities for educational leaders to shift the mindset of how we use our words to frame students.

The three themes of culture of respect, implementation of best practices, and social reproduction answer this study's research questions about how whiteness shows up in a classroom with a majority of English learners when best practices are implemented by an experienced teacher. Analysis of observations and interview responses revealed that the concept of respect was reduced to an expectation of compliance and good 
behavior by students, expressed by the teacher and internalized by students. Though compliance to rules is a critical function of an effective instructional environment, when imbued with whiteness, compliance is rewarded because it protects the dominant understanding of racial hierarchies while remaining virtually unacknowledged because it's interpreted as a form of respect.

Respect was characterized by positive teacher relationships, the influence of family values, and humanizing practices in the classroom. The second theme of best practice implementation for language learners included the strands teacher perception of student capability based on language proficiency, and assumptions about the adequacy and replication of best practice defined by literature. Together, these two themes flow into the third theme of social reproduction, which is characterized by how implicit bias and unacknowledged white privilege materialize in classrooms serving primarily students learning English, how teachers experience and replicate the constraints of the educational system, and how students internalize their own oppression based on the inherent and implied perceptions of their teachers. In summary, the findings from this study add to existing literature on the experiences of racialized students learning English and deepen our understanding of quantitative findings by highlighting the collective youth voices of a population that is rarely illuminated in qualitative research: elementary grade ELs and RFEPs. 


\section{Interpretation of Findings}

The findings in this study support existing literature on the pervasiveness of how unacknowledged whiteness and implicit bias manifest themselves in classrooms where English is not the primary language of students but is the only language of the teacher. The findings trouble the idea that research-based best practices, even those implemented as intended with full fidelity, work to their expected outcome, as we have no systematic way of measuring their effectiveness separate from the familial and peer supports to whom all participants attributed, at least in part, their achievement. Overall, I attempted to humanize the study's participants by allowing them to represent their own realities by using their words and voices to frame their experiences and, ultimately, these findings.

\section{Nuances of the Culture of Respect}

Scholars who center their work on the experiences of Latinx communities frequently emphasize the role that respect/respeto plays in academic achievement. Valenzuela (1999) defined the strong drive to succeed, which immigrant families instill in their children, as an outgrowth of the familial value of respect. Respect for teachers and an ambition for upward mobility through educational attainment are communal values that show up in classrooms as obedient and deferential comportment by students that is rewarded because it is consistent with mainstream teachers' expectations of appropriate behavior (Suarez-Orozco, 1991; Valenzuela, 1999). Compliance and docility, however, can also encourage a sense of powerlessness and a lack of entitlement when students like Lissette become too nervous and afraid to ask the teacher for help. Some 
white teachers' intentions with marginalized students can unintentionally reproduce whiteness by silencing students at the very intersections of power, equity, and academic engagement (Yoon, 2018).

The majority of students in this study defined their teachers using the word "nice;" however, only those who were classified as fluent English proficient expressed a personal story about connection to a teacher. None of the students classified as EL went beyond this one-word description of their teacher to share personal stories of engagement; instead they all highlighted the impact of their supportive peer relationships and encouragement from nuclear and extended family members. Right after he described his teacher as nice, Ivan told me he "kinda" thought he was a good student and elaborated: "Sometimes I get in trouble by not following directions... because I'm bored." Students explain being off-task as boredom when it's more often the case that they're having difficulty with an assignment, a different way of expressing the nervousness Lissette describes in asking for help from the teacher. My interpretation of this phenomenon is that the culture of respect in the classroom is nuanced and hierarchical based on how closely students replicate expected behaviors and language proficiencies of dominant English speakers. This interpretation is backed up by my analysis of the teacher's comments and interactions with students during classroom observations and is summed up in the quote that opens this chapter. On the surface, the idea of removing fault from students appears to be a humanizing practice by the teacher, however, enumerating the perceived and implied deficits of students contradicts the 
stated profession of the teacher that blame does not belong to students and their families. Add to this assertion that the teacher was unaware of her own deficit framing of students and the families who instill the value of respect within them and you begin to see how insipid the power dynamics of whiteness are in everyday interactions in American classrooms.

\section{Troubling the Idea of Best Practice}

While a culture of respect improves performance outcomes for ELs and improves critical self-reflection by practitioners, teacher perception of student capability has greater influence on outcomes because of the assumptions that best practices are replicable to all students who fit a particular demographic. Best practices were conceived to engage multiple modalities for learning and instructors need to have the capacity and knowledge to meet individual student needs based on all the variables, including the amount of effort a student is putting into "trying." Note-taking for the sake of simply copying from the board is not a best practice when supplemental support is not offered, in the form of further clarification or additional individualized help when requested. Student initiative and family support play a strong role in student achievement and proficiency, leading some students to do well regardless of the quality and quantity of teacher-led instruction and use of best practices. This is illustrated in Table 5, with much less than half of observed instructional time spent on actual teacher-led instruction. This individualized computer time becomes another avenue of interpreting how compliance and working quietly and independently are used as performance indicators by the teacher 
rather than measures of actual achievement when no additional planned instruction is delivered.

The teacher excerpt at the beginning of this chapter provides context for the problematic implementation of best practices geared at improving outcomes for students learning English. When language learners are seen as a monolithic population, researchbased best practices remove the relational imperative that grounds the culture of respect for individual experience in the classroom. Regardless of how Mrs. Pfeiffer set up her classroom with a fundamental understanding of respectful teacher-student relations, her repeated implications that students and their families lack experience, knowledge and language clearly demonstrates that implicit bias and unacknowledged white privilege are not innocuous, though they remain unaddressed. Nobel laureate Toni Morrison said eloquently and succinctly that "oppressive language does more than represent violence. It is violence." And though these words may not be blatant they create harm for the students, their families, and the institution of education, disguised in connotations of care.

\section{Disrupting Social Reproduction of Schooling}

With a strong anchor in what it means to define a culture of respect in the classroom, we can layer onto this understanding a perception of how a capable student is defined within this environment. Teacher perceptions of capable students are influenced by how best practices work, but because best practices do not work for everyone universally, it becomes a default coping mechanism for teachers and school leaders to come up with a way to explain high-stakes testing data. Too often, these explanations 
unload much of the blame onto the very students best practices are designed to help. Social reproduction and external pressures to achieve illuminate how whiteness shows up in educational institutions through the perpetuation of a reliance on implementation of socalled best practice, without attention to the influence of dominant features of the classroom culture.

\section{A Response to Policy}

The culture of respect and passive language acquisition characterized in this classroom may have its roots in recent policy shifts in California, which serve to shape the propagation of EL instruction out of synch with current frameworks in core academic subjects, namely that of problem solving and empowering students through mathematics and language arts. In 2012, the State of California adopted the new English Language Arts/English Language Development (ELA/ELD) framework, aligning language standards to new Common Core instructional standards. Many districts took this framework to heart and implemented new EL Master Plans to more effectively address the needs of the fastest growing segment of the school population (Albers \& Martinez, 2015). Four years later, in 2016, Proposition 58 was passed, implementing the California Multilingual Education Act. This is significant because it overturned the previous initiative - Proposition 227 - that was adopted in 1998 and required English learners to be taught exclusively in English immersion classrooms. For twenty years, pre-service programs and teachers in the classroom have been teaching under this model for language acquisition, despite what education and language acquisition research has long professed. 
Which means, in California, we have a whole generation of educators who need to be retrained with a mindset recalibration about how students acquire language and with a skill set that improves instructional practice. The new Multilingual Education Act requires that districts get input and feedback from families and other stakeholders in the community as part of the Local Control Funding Formula.

A year later in 2017, the State Board of Education adopted the English Learner Roadmap. According to the CDE, the Roadmap is a collection of resources available to assist districts as they implement "California's $21^{\text {st }}$ century college- and career-ready standards, curriculum, instructional programs, and assessments or English learners." This collection of resources presumes that lack of information is the primary challenge to improving outcomes for students; clearly that is not the case. If districts knew how to improve outcomes, there would be replicable programs of success.

Senate Bill 594 related to the EL Roadmap policy already on the books. This bill established a system of awarding grants to county offices of education, school districts, charter schools, and non-profit organizations with "demonstrated expertise in English learner instruction." The bill would appropriate $\$ 4,000,000$ in each of three years, starting during the 2020-2021 school year. The intent is to build capacity in bilingual and biliteracy proficiencies; however, much like the EL roadmap presumes lack of information is the obstacle, this proposal suggests that money is the incentive missing from achieving these proficiencies. None of these attempts at creating frameworks and writing policy have had the intended impact on improving overall outcomes for 
multilingual students, from the CDE to local districts. And the existing frameworks expand upon the traditional models of biliteracy and bilingual programs with less reliance on transformative ideas of translanguaging.

The budding theory of critical whiteness offers a response to traditional practices and new initiatives from the perspective that many privileges that flow to white people are invisible, unearned, and not consciously acknowledged, and these practices undergird and influence ideologies and stereotypes that reinforce institutional hierarchies and the larger system, particularly for historically racialized and marginalized groups, like English language learners (Picower, 2009). My findings suggest that, while policymakers have been concerned with the uptake of new practices, phenomenological evidence suggests there is more to unpack about the pernicious nature lurking underneath a culture of respect imbued with whiteness that may exist in many classrooms where such policies seek to have an impact, but which only help maintain and perpetuate the status quo.

The considerable number of white people in the teaching field and in positions of political power in a country marked by racial inequality has implications for the role white teachers and white legislators play in creating patterns of racial achievement and opportunity (Bonilla-Silva, 2003; Picower, 2009). Without addressing this phenomena directly, we perpetuate disadvantaged outcomes for students learning English while protecting the educators and policy-makers from reflection upon the role of white supremacy and self-preservation and their impact on these outcomes. Understanding how these invisible tools of whiteness protect the dominant understandings of race can advise 
teacher education programs and public policy lobbyists on how to transform ideologies in order to better level the field for all students (Elmore, 2007).

The prominence of unacknowledged whiteness and implicit bias were visible throughout my research. Whiteness and privilege frame the language used to define student experience, academic capability, and familial perception but without the recognition by white educators of its deficit implications. Whiteness and the false idea of meritocracy in the classroom need to be critically addressed in order to disrupt the social reproduction that is reinforced through the use of best practices to further marginalize and blame students for what are in fact structural inequities.

\section{Implications for Social Justice Leadership and Educational Equity}

To frame the steps a school leader must take to become culturally responsive, Khalifa et al. (2016) identified four categories that encompass their actions: critical selfreflection, developing culturally responsive school teachers and curriculum, promoting culturally responsive and inclusive school environments, and engaging students and parents in community contexts. Undertaking only the first and last elements of Khalifa's framework based on the scope of this study, a necessary initial step toward radical transformation and educational equity would be to enact regular opportunities for critical self-reflection by practitioners to unpack their own privilege and the deficit views that educational institutions espouse about racialized communities (Yosso, 2005).

Historically, schools have reached out to parents from marginalized communities primarily as a means to meet required quotas for representation on various campus 
leadership committees; however, asking parents from these communities to become deeply involved in the same school spaces that were detrimental to their own intellectual and socio-emotional well-being is problematic from a social justice perspective because it's another way of normalizing and perpetuating the treatment of marginalized students. Building authentic relationships with parents by establishing a two-way engagement for imparting knowledge is a huge undertaking that often gets overlooked when campus priorities are ranked, but in moving toward real transformation of educational institutions, this effort cannot continue to remain merely a formality.

Including parents as critical partners in delving into the familial roots of respect/respeto and explicitly addressing how that essential community value morphs into something that gets reinterpreted as compliance in school classrooms would encourage a renewed ownership by educational collaborators to unpack their own cultural understandings of privilege and complicity in sustaining an institution of conformity and deference, rather than one of academic rigor and educational equity.

On the surface, simply claiming that a culture of respect in classrooms can pose further marginalizing undercurrents for racialized students seems counterintuitive, which is why building relationships of equity and trust with parents is a vital step in humbling educators to the qualitative understandings of families and students in further disrupting the dominant power dynamics and reversing the flow of valued information from families to school practitioners and leaders. 


\section{Implications for Policy and Practice}

As noted in Chapter One, changing the language that practitioners use could lead to a significant shift in changing perception of students learning English. Though it seems like too simple a shift to have a desired impact on student experience, words matter, and requiring educators to actively think beyond the limited framework of labeling based on language proficiency could change the context more immediately and more thoroughly than any prolonged plan for implementation of professional development in building culturally sustaining capacity in educators. Sorting, labeling and defining students with terms like English Learner, or simply as EL, dehumanizes language learners in a way that the term students learning English does not. The latter term describes one aspect of a student's identity without affixing a capitalized label that stigmatizes. The term is less about demographic categorization and more about the humanity of individuals and their varied experiences in learning a new language.

Language beyond official policy is also deserving of renewed attention. In the course of my data collection, I reviewed comments on student cumulative folders and class placement cards filled out by previous teachers used to characterize these youth. Some were included in their portraiture. Some made me cringe. Terms and phrases like "bossy," "falls asleep, does NOTHING in class," "parents unresponsive," "coughs a lot," "low and slow," "easily distracted and distracts others," "needs to sit near the teacher to speed him up," "single parent," "referred for SPED testing," "inconsistent parent involvement," "incapable of working independently," "at-risk," and "he doesn't listen" 
are a small sample of the deficit language that teachers put on the official records that will travel with students throughout their careers. Though I do not include the assetlanguage used to describe these students here, I incorporated many of those descriptions in the student portraits, however, there were significantly fewer instances of positive language used to summarize each teacher's year of experience with my participants. When possessing a non-dominant language is described in terms of being a "barrier" and a "deficit," as named by Mrs. Pfeiffer, it reinforces the justification for the marginalizing practices that perpetuate poor outcomes and poor expectations for racialized students.

Policies that address bilingual education need to move beyond the minor tweaks in philosophy that impact instruction around best practices for English learners. Garcia and Li (2014) suggested the move beyond binary understandings of language development and traditional bilingual education models requires a shift in focus from the primacy of discrete language instruction and instead focus on the attributes of multifaceted speakers. Based on decades of research on performance outcomes, traditional measures of proficiency gaps for students classified as EL substantiate the claim that power is in the language and not with the speaker. Making a change in bilingual education policy and in teaching practice to level the hierarchical relationship of language as it's currently taught in bilingual programs, simultaneously validates bilingual communities that have already constructed a unitary bilingual voice through translanguaging (Garcia \& Li, 2014). Isolating language instruction based on named languages rather than allowing students to pull from their full repertoire of all their 
language skills is another form of unacknowledged whiteness being favored, particularly in light of the power differential between the dominant language of English and the other languages bilingual students bring to school with them that are often viewed as deficits.

Along the same lines of shifting mindset, providing on-going education and professional development for staff in areas of social justice education, critical pedagogy, and culturally relevant and culturally sustaining education would offer an opportunity for practitioners to regularly examine their beliefs about families and students, particularly in diverse communities where students learning English make up a significant portion of the school population, while also focusing on improving instructional practice through opportunities to implement culturally sustaining strategies. Opportunities for both selfreflection and access to instruction about historical oppression could provide educators and leaders with a regular practice of examining current educational inequities. Though similar recommendations to improve professional development opportunities have been made by influential scholars, the practical application of actually implementing meaningful change through systematic training of veteran practitioners becomes a prohibitive undertaking when the expanse of what this would entail is considered with so many educators in California public schools.

\section{Implications for Educational Leadership}

The deconstruction of oppressive institutional structures is necessary to make fundamental change. For many students and their families on the margins of dominant school culture, the educational experience has been dehumanizing. By valuing cultural 
practices that are different from the dominant white culture and validating student experience through their own self-advocacy and voice, school leaders can interrupt the socially reproductive practices that perpetuate continued marginalization.

Site and district administrators need to foster authentic and trusting relationships within and across the institution in order to implement meaningful self-reflective practice that speaks to prohibitive systems to student success and address personnel considerations that value longevity over instructional proficiency. For too long, the lowest performing teachers have ended up in the lowest performing classrooms and the students are the ones being blamed for the outcomes, paying the long-term price for lack of access to rigorous instructional standards. Educational leaders need to revisit this model and reimagine how it would be different in the absence of white supremacist institutional practices that protect the wrong people.

And in my own case of dealing with institutional practices that protect a leader who presents with symptoms of white fragility, it affords me first-hand experience in thinking through a lens of critical whiteness and the ramifications that this fragility can unleash on a school community. It is of particular importance, therefore, for selfidentified white leaders working in schools that enroll predominantly non-white students to think critically about race and privilege and reflect upon their practice.

\section{Recommendations for Further Study}

One recommendation for future research would be a study of teacher experiences in bilingual, dual-immersion, and translanguaging spaces with a disposition toward 
improving institutional practices for students learning English, both within their classrooms and structurally upon their campuses. And to address the perpetuation of white supremacy in institutional spaces, another topic of future research would be a study of educational administrators and leaders attempting to implement interventions intended to disrupt the practices of social reproduction and hierarchies of power based on unacknowledged privileges afforded by race, particularly in schools that serve non-white student populations and families.

\section{Limitations of the Study and Areas for Further Research}

Limitations of this study include a small number of participants and the attention to just one classroom dynamic at one district campus. Replicating this study at other schools in the district serving students at different grade bands and including more than one classroom at each observed site would corroborate the findings of this study and offer additional insight into the experiences of educational practitioners and students learning English.

\section{Reflections on the Research Process}

Throughout my career as an educator, I have sought opportunities to improve academic outcomes for marginalized student populations, but completing this research study has been the most impactful learning experience in my professional and educational career. It changed who I am as a practitioner and how I engage with families, campus communities, and fragile white educators in positions of authority. 
Another reflection made during the research process, framed through my critical white lens, is the ways in which whiteness works beyond the classroom. Based on personality and relationship with previous administrators, who are both white, the participant teacher in this study was recommended as one of the very best on campus. When professional characterizations are based on personal relationships, it further perpetuates disparities within classrooms and on campus.

As depicted in my revised conceptual framework, Figure 2, my thinking has shifted since the inception of this study. While I initially focused on the documented measures of classroom practice and the impact of teacher perception, I failed to realize the significance that an undercurrent of a culture of respect plays in the efficacy of teacher-student relationships and how that translates into students' sense of validation, even when there is not a common understanding of what respect looks like in a classroom. 


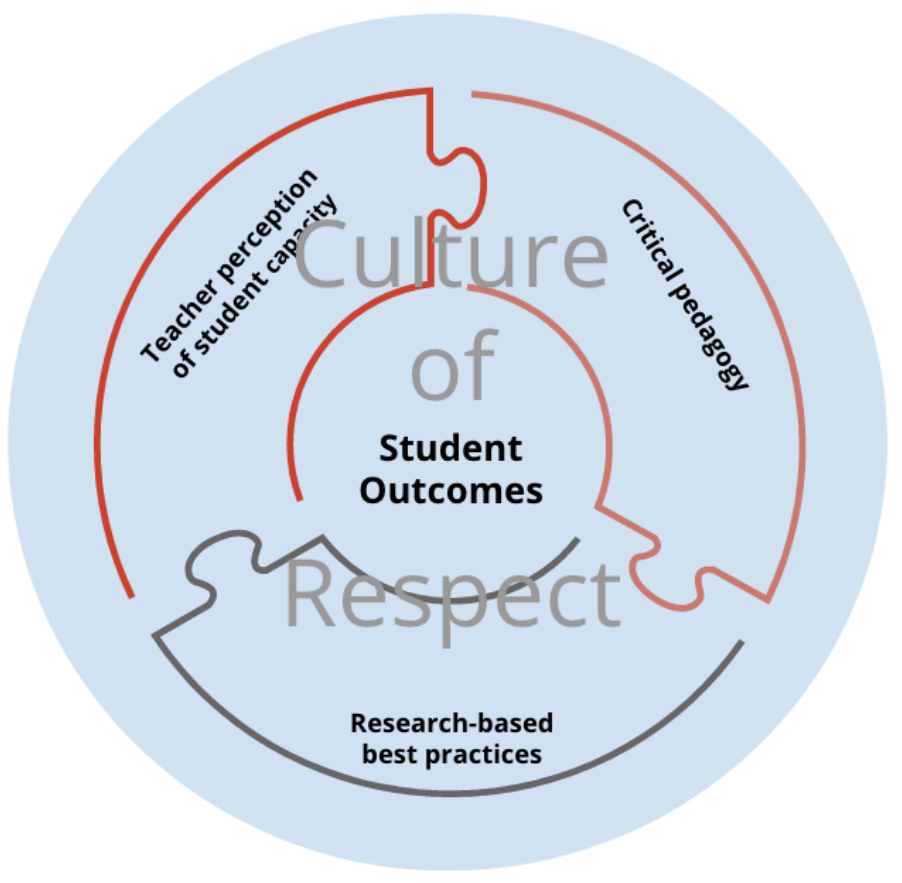

Figure 2. Revised Conceptual Framework. Revised to overlay the importance of the culture of respect on student outcomes in combination with instructional practices and teacher perception.

\section{Conclusion}

The impact of white supremacy on educational institutions is discernible in the structural practices that perpetuate inequities for racialized populations. These practices may appear innocuous at their surface, however, when viewed through a lens of critical whiteness, their nefarious applications illuminate the imperative to restructure institutions that perpetuate harm to students. Harm takes on various forms, but in the case of students learning English, the harm comes from the language that is used to describe and label them, from the language that categorizes them based on English proficiencies and that 
further marginalizes them based on perceived deficits in learning the language of the dominant culture.

It could be argued that any study emphasizing critical whiteness as its theory will infallibly point to only the problems of an institution. My intention throughout the course of conducting this research, however, was that I held at center a humanizing space for the families, the practitioners, and the youth of this school community by humanizing its participants. Through the lens of critical whiteness, I offer recommendations for transforming practice; however, I recognize that fast-tacking to solutions is not the sole aim of this study. There is something transformative about simply ruminating within the space that this lens creates and encourages us as practitioners to think about things more deeply beyond superficial understandings. Sometimes this rumination leads to action, but sometimes it simply spurs us to deeper self-reflection and awareness. 


\section{REFERENCES}

Albers, C. A., \& Martinez, R. S. (2015). Promoting academic success with English learners: Best practices for RTI. New York, NY: Guilford Press.

Banks, J. A. (2001). Cultural diversity and education: Foundations, curriculum, and teaching. Boston, MA: Allyn \& Bacon.

Bonilla Silva, E. (2003). Racism without racists: Color-blind racism and the persistence of racial inequality in the United States. Lanham, MD: Rowan \& Littlefield Publishing Group.

Bourdieu, P., \& Passeron, J. (1977). Reproduction in education, society and culture. London, UK: Sage.

Braudel, F. (1958). History of social sciences: The long duree. Cambridge, UK: Cambridge University Press.

Celedon-Pattiches, S., \& Ramirez, N. (2012). Beyond good teaching: Advancing mathematics education for ELLs. Reston, VA: National Council of Teachers of Mathematics.

Crowley, R. (2016). White teachers, racial privilege, and the sociological imagination. Urban Education, 1-27.

De Araujo, Z., Roberts, S. A., Willey, C., \& Zahner, W. (2018). English learners in K-12 mathematics education: A review of the literature. Review of Educational Research, 88(6), 879-919. 
DiAngelo, R. (2018). White fragility: Why it's so hard for white people to talk about racism. Boston, MA: Beacon Press.

DiCerbo, P. A., Anstrom, K. A, Baker, L. L., \& Rivera, C. (2014). A review of the literature on teaching academic English to English language learners. Review of Educational Research, 84(3), 446-482.

Duncan-Andrade, J., \& Morrell, E. (2008). The art of critical pedagogy: Possibilities for moving from theory to practice in urban schools. New York, NY: Peter Lang Publishing.

Elmore, R. (2007). School reform from the inside out: Policy, practice, and performance $\left(4^{\text {th }}\right.$ ed.). Cambridge, MA: Harvard Educational Press.

Foucault, M. (1977). Discipline \& punishment. New York, NY: Random House.

Frankenberg, R. (1993). Critical white studies. Philadelphia, PA: Temple University Press.

Garcia, O., \& Li, W. (2014). Translanguaging: Language, bilingualism and education. Blasingstoke, UK: Palgrave Macmillan.

Gee, J. (1989). What is literacy? Journal of Education, 171(1), 18-25.

Gutierrez, R. (3013). The sociopolitical turn in mathematics education. Journal for Research in Mathematics Education 44, 37-68.

Haas, E., \& Gort, M. (2009). Demanding more: Legal standards and best practices for English language learners. Bilingual Research Journal, 32(2), 115-135. 
Institute of Educational Sciences. (2020 April 5). What Works Clearinghouse. Retrieved from https://ies.ed.gov/ncee/wwc.

Jupp, J. C., Berry, T. R., \& Lensmire, T. J. (2016). Second-wave White teacher identity studies: A review of White teacher identity literatures from 2004 through 2014. Review of Educational Research, 20(10), 1-41.

Kendi, I. X. (2016) Stamped from the beginning: The definitive history of racist ideas in America. New York, NY: Hachette Book Group.

Kendi, I. X. (2019). How to be an antiracist. New York, NY: Random House.

Khalifa, M. A., Gooden, M. A., \& Davis, J.E. (2016). Review of Educational Research 86(4), 1272-1311.

Kleinfeld, J. (1975). Effective teachers of Eskimo and Indian students. School Review 83, 301-344.

Ladson-Billings, G. (1995). Toward a theory of culturally relevant pedagogy. American Educational Research Journal, 32, 465-491.

Ladson-Billings, G. (2006). From the achievement gap to the education debt: Understanding achievement in U.S. schools, Educational Researcher 35(7), 3-12.

Lawrence-Lightfoot, S., \& Hoffman Davis, J. (1997). The art and science of portraiture. Jossey-Bass.

Lawrence-Lightfoot, S. (2016). Portraiture methodology: Blending art and science. Learning Landscapes, 9(2), 19-27. 
Leonardo, Z. (2002). The souls of white folk: Critical pedagogy, whiteness studies, and globalization discourse. Race ethnicity and education 5(1), 29-50.

Li, N. (2013). Seeking best practices and meeting the needs of the English language learners: Using second language theories and integrating technology in teaching. Journal of International Education Research 9(3), 217-222.

Long, S., Souto-Manning, M., and Vasquez, V. M. (2016) Courageous leadership in early childhood education: Taking a stand for social justice. New York, NY: Teachers College Press.

McIntosh, P. (1988). White privilege: Unpacking the invisible knapsack. Philadelphia, PA: Temple University Press.

Menken, K. (2013). Restrictive language education policies and emergent bilingual youth: A perfect storm with imperfect outcome. Theory Into Practice 52, $160-168$.

National Center for Education Statistics (2015). National teacher and student demographics. Retrieved from http://www.nces.ed.gov

Oakes, J. (2005). Keeping track: How schools structure inequality (2nd ed.). New Haven, CT: Yale University Press.

Picower, B. (2009). The unexamined whiteness of teaching: How white teachers maintain and enact dominant racial ideologies. Race Ethnicity and Education, 12(2), 197-2115.

Saldana, J. (2016). The coding manual for qualitative researchers. Sage. 
Suarez-Orozco, C., Pimentel, A., \& Martin, M. (2009) The significance of relationships: Academic engagement and achievement among newcomer immigrant youth. Teachers College Record, 111(3), 712-749.

Tatum, B. (1992). Talking about race, learning about racism: The application of racial identity development theory in the classroom. Harvard Educational Review, $62(1), 1-25$.

Tatum, B. (1997). Why are all the black kids sitting together in the cafeteria?: And other conversations about race. New York, NY: Basic Books.

Valenzuela, A. (1999). Subtractive schooling. Albany, NY: SUNY Press.

Van Manen, M. (2014). Phenomenology of practice: Meaning-giving methods in phenomenological research and writing. New York, NY: Routledge.

Ware, F. (2006). Warm demander pedagogy: Culturally responsive teaching that supports a culture of achievement for African American students. Urban Education, 41(4), 427-456.

Yoon, I. (2018). Silencing racialized humor in elementary school: Consequences of colormuting and whiteness for students of color. Berkeley Review of Education, $8(1), 117-144$.

Yosso, T. J. (2005). Whose culture has capital? A critical race theory discussion of community cultural wealth. Race Ethnicity and Education, 8(1), 69-91. 


\section{APPENDIX A \\ Student Assent to Participate in Research \\ San Francisco State University \\ Agreement to Be Part of a Research Study}

I am studying for my doctorate degree in education. I'm writing a paper about students who know more than one language and how they experience school.

I will be working with your teacher to visit your class to see regular instruction and participation. I will also interview you up to three times individually and perhaps one time as a group. This will allow me to get to know you and understand your experience in school.

Your participation is voluntary. You don't have to participate. Your grade will not be affected either way.

If you don't want to participate, just do not sign this form.

Thank you,

Ashley Waggle

Researcher's signature Date

Student's name Date

Student's signature Date 


\section{APPENDIX B \\ Teacher Assent to Participate in Research \\ San Francisco State University}

Purpose of Research

My name is Ashley Waggle. I am a graduate student at San Francisco State University and I am conducting a research study about the experience of multilingual students. I am inviting you to participate in the research because you were recommended to me as an instructor of high regard.

\section{Research Procedures}

If you agree to participate, I will interview you at a time and location convenient for you. The interview will take about 30 minutes, and I will audiotape the interview to make sure I understand what you have said. I will also observe instruction in your room for approximately 20 hours over 6 weeks. If I need to clarify your statements, I will contact you after the interview. If you are willing to keep and share a reflective journal throughout this process, it would be appreciated, but not expected. I may ask for a follow-up interview on your insights regarding focal students at the conclusion of my classroom observations.

\section{Risks}

The only risk to you is a possible loss of privacy. To protect your privacy, I will keep the audiotapes and transcripts of the interviews in a locked cabinet in a secure location to ensure the confidentiality of the data on my personal devices only. I will not use your name or any other identifying information in the research reports. At the end of the study, I will destroy the recordings, and will remove all identifying information from transcripts.

Benefits

There is no direct benefit to you for taking part in the research. However, I hope that what we find may inform educators and administrators about students' experience and identity.

Costs and Compensation

There will be no costs to you other than your time. You will not be paid for participation.

You have been given a copy of this consent to keep. If you have any questions about the research you may contact my Committee Chair, Dr. Maria Zavala at mza@sfsu.edu or you may contact the Director of the Educational Leadership, Dr. Barbara Henderson at barbarah@sfsu.edu, or Human and Animal Protections at protocol@sfsu.edu or 415-338-1093.

Please note that participation in research is voluntary. You may answer only those questions you want to answer, and you may stop participating at any point in the process with no penalty. 
Participants Signature

Date

Researcher's Signature

Date 


\title{
APPENDIX C
}

\section{Parental Permission for Minor to Participate in Research: English Version}

\author{
Dear Parent or Guardian:
}

My name is Ashley Waggle. I am the new Academic Coordinator at MacDougal Elementary School and a graduate student in the Educational Leadership Doctoral Program at San Francisco State University. I am doing a study on the impact of teacher perception on students' ability, as it relates to language acquisition, and how that perception influences student effort and performance. The primary goal of this study is to positively impact the academic and self-efficacy outcomes for all students, but most especially language learners. The Superintendent and Cabinet have given their approval for me to conduct this research at MacDougal.

I am particularly interested in hearing from students as part of this study. With your permission, your student will be asked to participate in this study because s/he was recommended by a teacher or administrator, and/or because of their performance on various assessments that would make her/him a candidate for sharing an academic experience. If you allow your student to participate in this activity, the following guidelines will be followed:

- Students will meet with me at lunch or before school to answer any questions they may have about the process

- On the day of the interviews, students will meet with me in a neutral place of their choosing and I will audio record their collective responses to my prepared questions, related to their personal experiences and feelings about school. Their responses will be transcribed.

- Students will be invited for a debrief on the process to discuss any feeling that may have come up from their participation in this project

While there will be no direct benefit for your student from participating in this study, the anticipated benefit of this study is to prompt meaningful discussion on a very sensitive topic. Hopefully, the opportunity for self-reflection and empowerment will benefit student participants overall.

Participation is entirely voluntary; you and your student are free to decline to participate in this study, or to withdraw from it at any point. Because students will be audio recorded, confidentiality will necessarily be compromised, but the use of the recording will be used expressly for professional development and research purposes.

If you have any questions about this research, you may contact me via email at: ashley_waggle@*****.net or by phone at 728-6315. If you have further questions about the study, you may contact the Institutional Review Board for the Protection of Human Subjects at San Francisco State University, which is concerned with the protection of volunteers in research projects. 
Thank you for your attention. If you agree to allow your student to participate, please complete the information below and return to the main office.

Respectfully,

Ashley Waggle

_ Yes, I understand the purpose of the audio recorded research project and agree to allow my student to participate.

__ No, I do not give permission for my student to participate in this project.

Student Name:

Parent Name:

Phone:

Parent Signature:

Date:

Comments: 


\section{APPENDIX D \\ Parent Permission for a Minor to Participate in Research: Spanish Version}

\section{Estimado padre o tutor:}

Mi nombre es Ashley Waggle. Soy la nueva Coordinadora Académica en la Escuela Primaria MacDougal y un estudiante graduado en el Programa de Doctorado en Liderazgo Educativo en la Universidad Estatal de San Francisco. Estoy haciendo un estudio sobre el impacto de la percepción de los maestros en la capacidad de los estudiantes, en lo que se refiere a la adquisición del lenguaje, y cómo esa percepción influye en el esfuerzo y el rendimiento de los estudiantes. El objetivo principal de este estudio es impactar positivamente los resultados académicos y de autoeficacia para todos los estudiantes, pero especialmente los estudiantes aprendices de idiomas. La Dra. Rodríguez y el Gabinete me dieron su aprobación para realizar esta investigación en MacDougal.

Estoy particularmente interesada en escuchar a los estudiantes como parte de este estudio. Con su permiso, se le pedirá a su estudiante que participe en este estudio porque un maestro o administrador lo recomendó, y / o debido a su desempeño en varias evaluaciones que lo convertirían en un candidato para compartir una experiencia académica. Si permite que su estudiante participe en esta actividad, se seguirán las siguientes pautas:

- Los estudiantes se reunirán conmigo en el almuerzo o antes de clases para responder a cualquier pregunta que puedan tener sobre el proceso

- El día de las entrevistas, los estudiantes se reunirán conmigo en un lugar neutral de su elección y grabaré en audio sus respuestas colectivas a mis preguntas preparadas, relacionadas con sus experiencias personales y sentimientos sobre la escuela. Sus respuestas serán transcritas.

- Se invitará a los estudiantes a un informe sobre el proceso para discutir cualquier sentimiento que pueda surgir de su participación en este proyecto.

Si bien no habrá un beneficio directo para su estudiante al participar en este estudio, el beneficio anticipado de este estudio es generar una discusión significativa sobre un tema muy delicado. Con suerte, la oportunidad de auto-reflexión y empoderamiento beneficiará a los estudiantes participantes en general.

La participación es totalmente voluntaria; usted y su estudiante son libres de negarse a participar en este estudio, o retirarse de él en cualquier momento. Debido a que los estudiantes serán grabados en audio, la confidencialidad será necesariamente comprometida, pero el uso de la grabación será expresamente con fines de investigación y desarrollo profesional.

Si tiene alguna pregunta sobre esta investigación, puede contactarme por correo electrónico a: ashley_waggle@*****.net o por teléfono al $728-* * * *$. Si tiene más preguntas sobre el estudio, puede comunicarse con la Junta de Revisión Institucional para la Protección de 
Asignaturas Humanas en la Universidad Estatal de San Francisco, que se ocupa de la protección de voluntarios en proyectos de investigación.

Gracias por su atención. Si acepta permitir que su estudiante participe, complete la información a continuación y devuélvala a la oficina principal.

Respetuosamente, Ashley Waggle

Sí, entiendo el propósito del proyecto de investigación grabado en audio y acepto permitir que mi estudiante participe.

No, no doy permiso para que mi estudiante participe en este proyecto.

Nombre del estudiante:

Nombre del padre:

Teléfono:

Firma del padre: Fecha:

Comentarios: 


\begin{abstract}
APPENDIX E
Student Interview Questions

Interview One: Life and Educational History

The first interview will focus on the students' life history and self-perceptions.

1. Tell me about yourself; describe your:

- Family

- Community/neighborhood

- Age/Grade

- Schools you've attended/teachers you've had

o Were the schools you attended considered "good schools"|"good teachers"? Why or why not?

o How do you see your academic performance in school?

o What factors do you think influence your performance?

o How has being a multilingual student influenced your experience in school?

o What activities make you feel engaged and interested in what you're learning?
\end{abstract}

2. How would you describe yourself academically?

- Tell me about a time you felt really successful at school, or a time you were proud of yourself about a school achievement.

3. What do you believe has contributed most to your academic success?

4. Have any of your family members or community members played a role in your academic success? If so, how?

5. Are there any skills or beliefs that you have developed in your family and/or communities that have helped you succeed in school? What about skills or beliefs you have developed at school? 
6. Can you name one or two people - family or school or community - who have been influential in your life? What strengths do these people have? What skills do they have that you value?

Interview Two: In-School Experiences and Language

This interview will focus on student interactions with peers and adults during their early elementary years, as well as their current experiences in school. Particular attention will be paid to multilingualism and language acquisition.

1. Who are the groups of people, or individuals, who support you most in your academic career?

2. Do you face any challenges as a multilingual student? If so, what are they?

. Do you believe you are overcoming these challenges? If so, how?

3. Do you believe your language identity impacts how community members and school personnel view you as a student?

4. What reactions do you get from peers in school, and peers in the community, regarding your academic performance/achievement?

5. When you think of a "multilingual student from Watsonville" what images come to mind?

Do these images fit how you see yourself?

- How are you different, or the same, as those images/words?

\section{Interview Three: Reflection on Skills}

The third interview will focus on student aspirations and reflections on their navigation of different contexts.

1. Do you want to go to college? Have a career? Why or why not?

Which colleges would you like to attend? Or which careers?

2. What career path would you like to pursue? Why? 
3. What skills do you believe you have that help you achieve in school? Do you think you achieve in school?

4. Do you act the same in school as you do outside of school (language, actions, other)? Why or why not?

5. Do you believe you are successful? If so, is it because of natural qualities within yourself, or because of your family/community, or school? Or a combination? Please explain.

6. Why is MacDougal the school you attend?

- Do you believe your experiences would be different if you attended a different school? Why? 


\section{APPENDIX F \\ Teacher Interview Questions}

1. What motivated you to become an educator?

2. What's your philosophy of education?

3. Tell me about your credentialing experience.

4. Describe your experience teaching at Amesti.

- How long have you been a teacher? Here? Total?

- Describe an experience when you felt your teaching was effective. What made it effective?

- Tell me about a time when you felt that your teaching was ineffective. Why do you feel it was ineffective?

5. Given your experience, what are practices that you see help students be successful, particularly multilingual students?

6. How would you describe a "struggling student"? Have you seen these students in your classroom? Have students expressed their struggles to you? How did they express them to you and how did you respond?

- Do you access behavioral and academic data to make determinations about students?

- What data do you use?

- How does this data impact your response?

- Give some examples of challenging students you have worked with.

7. What are your biggest challenges with students? 


\section{APPENDIX G}

\section{Follow Up Teacher Interview Questions}

1. You expressed some struggles and challenges with your own experience in the teaching profession. What are the core values that keep you dedicated to the teaching?

2. The concept of "patience" comes up several times in our first interview. What does "patience" mean to you? Why is it so important in your chosen profession?

3. You mentioned that students pick up habits from what they see, and you humanize students by saying "it's not their fault." What is "it"? How do you think your teaching addresses the "it"?

4. Can you talk more about the "learning gap"? For context from our previous interview:

Question: What's your biggest challenge with ELs?

Answer: I think it's the learning gap. I think that's really challenging. You never know how far down to go.

5. There is evidence of implementation of best practices in your instruction. What do you consider best practices, particularly around supporting students classified as EL and RFEP? What are your assumptions about how these practices are helping students?

6. Can you tell me what it means for a student to demonstrate that they are "good" at math? Or reading?

7. There are a lot of really great elements happening in your classroom. How would you define your greatest successes and skills? With that in mind, what challenges, tensions, or obstacles frustrate you most? 
8. You stated a couple of times that you "don't even know what (your) job is" supposed to be, and I know the most recent focus on data has been tough for you professionally and personally. If you had to define your job today, what would you say?

9. One thing I noticed during my observations was how compliant students are. Can you tell me more about your philosophy on student engagement and relationship, and what you do to set up the expectations for your class?

10. I noticed frequently during instruction that students were copying vocabulary definitions off the board during math and writing/reading. What is your purpose for having students copy what you've written from the board?

11. You've shared with me how you feel about Bridges. It's listed on your daily agenda, however, it didn't always happen when specified. Tell me about that and about how you implement Number Corner. Is this about the program itself or about students being able to access it?

12. There will be a section of my paper where I need to address the impact of leadership on classroom practice. Considering the context of your/our current leadership situation, how do you see a way leadership can positively impact classroom outcomes? Advice? 


\section{APPENDIX H}

District Reclassification Criteria for 2019-2020, as depicted in the EL Master Plan, approved March 2019

\begin{tabular}{|c|c|c|c|}
\hline & \multicolumn{3}{|c|}{ Grade Level Measures } \\
\hline $\begin{array}{l}\text { Multiple } \\
\text { Criteria }\end{array}$ & $\begin{array}{l}\text { 1st and } 2 \text { nd } \\
\text { Grade (Fall) }\end{array}$ & $\begin{array}{c}\text { 2nd Grade } \\
\text { (Winter/Spring) }\end{array}$ & 3rd-12th Grade \\
\hline $\begin{array}{l}\text { English } \\
\text { Language } \\
\text { Proficiency } \\
\text { (ELPAC) }\end{array}$ & $\begin{array}{l}\text { ELPAC } \\
\text { Proficiency: } \\
\text { Overall score of: } \\
\text { 4-Well Developed }\end{array}$ & $\begin{array}{l}\text { ELPAC Proficiency: } \\
\text { Overall score of: } \\
\text { 4-Well Developed }\end{array}$ & $\begin{array}{l}\text { ELPAC Proficiency: Overall score of: } \\
\text { 4-Well Developed }\end{array}$ \\
\hline $\begin{array}{c}\text { Academic } \\
\text { Achievement }\end{array}$ & $\begin{array}{l}\text { "Meets } \\
\text { Expectations" at } \\
\text { grade level for } \\
\text { Reading in English } \\
\text { during most } \\
\text { recent } \\
\text { assessment } \\
\text { window }\end{array}$ & $\begin{array}{l}\text { NWEA MAP RIT } \\
\text { Reading Score at or } \\
\text { above mean during } \\
\text { most recent } \\
\text { assessment window }\end{array}$ & $\begin{array}{l}\text { SBAC English Language Arts at or } \\
\text { above the midpoint of "Nearly Met" } \\
\text { (Level 2) } \\
\text { OR } \\
\text { NWEA MAP RIT Reading Score } \\
\text { at or above grade-level mean } \\
\text { during most recent } \\
\text { assessment window } \\
\text { OR } \\
\text { NWEA MAP RIT Reading Score at or } \\
\text { above 10th grade end of year mean }\end{array}$ \\
\hline $\begin{array}{c}\text { Teacher } \\
\text { Evaluation }\end{array}$ & $\begin{array}{l}\text { Report of } \\
\text { Progress indicates } \\
\text { that student is at } \\
\text { or above grade- } \\
\text { level standards in } \\
\text { all areas. }\end{array}$ & $\begin{array}{l}\text { Report of Progress } \\
\text { indicates that student } \\
\text { is at least approaching } \\
\text { standards in all areas. }\end{array}$ & $\begin{array}{l}\text { Report of Progress indicates that } \\
\text { student is at least approaching } \\
\text { standards in all areas. } \\
\text { ( } 2 \text { or C-, depending on grade level) }\end{array}$ \\
\hline $\begin{array}{l}\text { Parent Input } \\
\text { and } \\
\text { Consultation }\end{array}$ & $\begin{array}{l}\text { Parental opinion } \\
\text { and consultation }\end{array}$ & $\begin{array}{l}\text { Parental opinion and } \\
\text { consultation }\end{array}$ & Parental opinion and consultation \\
\hline
\end{tabular}

